\title{
Professor R.B. Singh (1955-2021), an Icon of Indian Geography: A Passage on the Path of Lineage, Legacy and Liminality
}

Rana P.B. Singh ${ }^{+}$

\section{Abstract}

Professor R.B. Singh (1955-2021) had been the first Indian Geographer to have the dual distinction of holding the position of the IGU Secretary General and ICSU Scientific Committee Member. He was the first Indian and second Asian Secretary General and Treasurer of the IGU (2018-2022). Professor Singh was a distinguished geographer of 21st Century India who had made distinct academic contributions over the last five decades, illustrated with publishing 16 books, 40 anthologies, and around 260 research papers. He has covered and profusely published researches in 11 fields-Environmental Studies, Geoecology; Land resources, Land use/ Land cover; Water issues, Hydrology; Disaster, Natural Hazard; Quality of Life, Livelihood; Climatic Change, Air Pollution study; Urban Environment, Health, and wellbeing; Sustainable Development Goals (SDGs); Environmental Monitoring; Geography, Development Studies R-U; Mountain Studies, Forestry, Tourism; and RS, GIS, Recent trends appraisal. He had supervised 39 PhD and 81 MPhil dissertations. This paper presents an appraisal of his life journey on the path of Lineage, Legacy and Liminality - a type of biographical highlights in the frame of his practising geography, while also emphasising various niches, distinctions, networks and collaborative programmes.

Keywords: R.B. Singh; Lineage; IGU, Secretary General; Environmental Studies, Climatic Change; Mountain Studies; Future Vision

\footnotetext{
${ }^{\dagger}$ Former Professor \& Head (2013-2015), Department of Geography, Institute of Science, Banaras Hindu University, Varanasi, Uttar Pradesh 221005, India. Professor Singh is the President- ACLA, Asian Cultural Landscape Association (Korea-India), Email: ranapbs@gmail.com

(C) 2021 Singh. This is an Open Access article distributed under the terms of the Creative Commons Attribution License (http://creativecommons.org/licenses/by/2.0), which permits unrestricted use, distribution, and reproduction in any medium, provided the original work is properly cited.
} 


\section{Introduction}

Geography is basically rooted in the spirit of place (genius loci), which one experiences, understand, memorises and further expands in one's lifeworld. I remember the saying by a great Irish geographer, Anne Buttimer (1938-2017), that "in each person's life echoes the drama of his or her times and milieu; in all, to varying degrees, the propensity to submit or rebel. Through our biographies we reach toward understanding, being and becoming" (Buttimer 1983, p. 3). On this line, the present appraised paper attempts to describe the journey and contributions of (late) Professor Ram Babu Singh (known popularly as R.B. Singh/RBS) with a supplement of proving overall view and enlisting all his publications (see Appendix 1 ) and the doctoral dissertations (see Appendix 2) supervised by him.

Since 1989 after having 6-months training under UNITAR/UNEP- GRID and EPFL (Switzerland), Professor R.B. Singh had followed the path what once Jack Dangermond (b. 1945-), an American billionaire businessman and a long-time member of the National Geographic family and the CEO of ESRI, said: "[o]ur world is evolving without consideration, and the result is a loss of biodiversity, energy issues, congestion in cities. But geography, if used correctly, can be used to redesign sustainable and more liveable cities" (see, Dangermond 2019, ref.). This is profusely represented in RBS's publications, mostly together with his doctoral students to whom he insisted and inspired to work on such contemporary and multidisciplinary themes; he had lived over three decades (1990 onwards-) of his geographic life, creating geography what the proverb says "Geography is what geographers can do". In a National Geographic Bee competition, held on 24 May 2012, US President Barack Obama, participated and has exposed his perception of geography: "The study of Geography is about more than just memorizing places on a map. It's about understanding the complexity of our world, appreciating the diversity of cultures that exists across continents. And in the end, it's about using all that knowledge to help bridge divides and bring people together" (see, Tau 2012, ref.). This image was part of the life-long journey by R.B. Singh, who was perceived 'an Icon of Indian Geography' in this quarter of the 21st Century, which was disseminated and received popularity at the global level through his colossal mass of publications and networking, and several international projects (see, Tables 1 and 2).

Professor R.B. Singh's sense of understanding village ecology goes back to his earlier days of courses in master's class with the collaboration of his teacher and elder brother (myself), illustrated with a study of their native village, Majhanpura (Bihar), and resulted in a monograph publication, viz. Singh and Singh Changing Frontiers of Indian Village Ecology (1981). In his foreword, Professor Walther Manshard (Secretary-General IGU) has remarked, "I hope that this study will reflect a new direction for an interdisciplinary approach and inspire fellow workers for the detailed investigation of the micro-level rural habitat. With this objective, I wish for its success and wide dissemination" (Singh \& Singh 1981, p. 9). Another noted American geographer, Professor Brian J. Murton (University of Hawaii, Honolulu), has opined: "[i]t is an excellent statement of how rural geography should be carried out, and where it should be directing its findings: not only to the theoretical realm of formal geography, but to the real world of rural problems and their solutions" (Singh \& Singh 1981, p. 11). Professor R.L. Singh (1917-2001), the Dean and father of modern geography in India has noted, "I am sure 
that this study will promote a greater not be slow to pursue similar research, and also interdisciplinary approach in integrated rural to implement the measures suggested by the development programmes in the developing authors in village level planning" (Singh \& Singh countries with similar environs; at the same 1981, p.10).

time, fellow workers and country-planners will

\begin{tabular}{|c|c|c|}
\hline Se & Year & Major Projects \\
\hline 1. & 1994 & $\begin{array}{l}\text { Director: Ministry of Agriculture Project for Preparation of Perspective Plan for } \\
\text { Land Resources in North Zone, India. }\end{array}$ \\
\hline 2. & 1994-1997 & $\begin{array}{l}\text { Co-investigator-CIDA-SICI Partnership Project-I on Sustainable Development of } \\
\text { Mountain Environment in India and Canada, Univ. of Delhi \& Univ. of Manitoba, } \\
\text { Canada. }\end{array}$ \\
\hline 3. & $2000-2002$ & $\begin{array}{l}\text { Director, DFID Res. Project on Enhancing Food Chain Integrity...Pollution Impact } \\
\text { on Vegetable System in Peri-Urban Areas, Collaboration with Imperial College, } \\
\text { London, UK. }\end{array}$ \\
\hline 4. & 1998-2002 & $\begin{array}{l}\text { Co-investigator-CIDA-SICI Partnership Project-II on Urban Development and } \\
\text { Environmental Impacts in Mountain Context, Univ. of Delhi \& Univ. of } \\
\text { Manitoba, Canada. }\end{array}$ \\
\hline 5. & 1997-2002 & $\begin{array}{l}\text { Director: ICSSR -Indo-Dutch Programme on Alternative in Development (IDPAD) } \\
\text { on Environmental Implications and its Socio-Economic Implications in Rural- } \\
\text { Urban Fringe of Delhi -Univ. of Delhi \& Univ. of Groningen, The Netherlands. }\end{array}$ \\
\hline 6. & 2003-2005 & $\begin{array}{l}\text { Co-Investigator: Shastri Applied Research Project (SHARP) on Role of Public, } \\
\text { Private and Civil Sectors in Sustainable Environment Management; collaborated } \\
\text { with University of Manitoba and the University of Winnipeg, Winnipeg, Canada. }\end{array}$ \\
\hline 7. & 2012-2014 & $\begin{array}{l}\text { Principal Investigator: Livelihood Security in Changing Socio-Economic } \\
\text { Environment in Himachal Pradesh, India collaborated with University of Turku, } \\
\text { Finland. }\end{array}$ \\
\hline
\end{tabular}

Table 2: Prof. R.B. Singh: Frequency of all the Publications by themes, 1979-2021 (see, Appendix: 1)

\begin{tabular}{|l|l|l|l|l|l|l|l|}
\hline Se & Broad Theme & T-4* & T-5 & T-6 & T-7 & T-8 & T-9 \\
\hline 1. & Environmental Studies, Geoecology & 1 & 9 & 2 & 5 & 5 & 3 \\
\hline 2. & Land resources, Land use/ Land cover & -- & 7 & 6 & 7 & 13 & 7 \\
\hline 3. & Water issues, Hydrology & -- & 1 & 15 & 7 & 4 & 5 \\
\hline 4. & Disaster, Natural Hazard & 3 & 2 & 3 & 7 & 6 & 14 \\
\hline 5. & Quality of Life, Livelihood & -- & 1 & 1 & -- & 1 & 5 \\
\hline 6. & Climatic Change, Air Pollution study & 3 & 6 & 13 & $1-$ & 4 & 2 \\
\hline 7. & Urban Environment, health, wellbeing & 1 & 1 & 4 & -- & -- & 1 \\
\hline 8. & SDGs, Environmental monitoring & 3 & 7 & 2 & 3 & 7 & 4 \\
\hline 9. & Geography, Development Studies R-U & 2 & -- & 4 & 9 & 6 & 9 \\
\hline 10. & Mountain studies, Forestry, Tourism & -- & -- & 10 & 5 & 9 & 20 \\
\hline 11. & RS, GIS, Recent trends appraisal & -- & -- & 4 & 9 & 3 & 6 \\
\hline 12. & Regional Science \& SDGs & -- & 2 & -- & -- & -- & -- \\
\hline 13. & INSA Geography Report, \& related & 3 & 4 & -- & -- & -- & -- \\
\hline-- & ALL & 16 & $\mathbf{4 0}$ & $\mathbf{6 4}$ & $\mathbf{6 2}$ & $\mathbf{5 8}$ & $\mathbf{7 6}$ \\
\hline
\end{tabular}

* T, Table. T-4 Books; T-5 Edited Volumes; T-6 Papers- Peer Reviewed; T-7 Papers in Indian Jls./ Books; T-8 Papers in International Books \& Proceedings; T-9 Papers in Indian Books \& Proceedings 


\section{Family \& Home: Lineage and Childhood}

R.B. Singh [Ram Babu Singh, RBS] was a descendant from a farmer's family settled in an underdeveloped and traditional countryside of Bihar, central India, named Village Majhanpura ( $25^{\circ} 50^{\prime} 05^{\prime \prime} \mathrm{N}$ latitude and $84^{\circ} 34^{\prime} 54^{\prime \prime}$ E longitude, in Saran district). We belonged to the BarahiyaSengar Rajputs, of the Gautam Gotra clan group, descendent from our progeny Bir Singh, and founding father of our lineage was Sujan Singh (ca 1715--1795). In the early 16th Century, the descendants of Bir Singh, the founder of the Lakhneshar Pargana (Ballia district), have migrated eastward in four successive waves (Singh and Singh 1981, p. 22). The first branch settled in the western part of the modern Saran district in five villages, viz. Nachap, Mahui, Gauspur, Bhuili and Bharhopur.

The second branch moved towards the northern side and also settled in five villages - Dighwa, Katalpur, Kabirpur, Basauli, and Hemuchapra. Another branch that is relatively later in date and known after Bir Singh, as Barahiya Rajputs occupied scattered sites near their kinsettlement, for example, Baghauna, Jamanpura, Kopa Majhanpura, Tahirpur, etc. However, in this part of our native village, the Sengar Rajput clan has established their kingdom during the early 13th Century, and by the end of the Century the clan moved to Lakhnesar Pargana of Ballia district, from where they spread in the tract between the Ganga and the Sarayu (Ghaghara) rivers (doab), and further from there along the Sarayu river in Saran district of Bihar (cf. Singh 1977, p. 100). Finally, the descendants of Sujan Singh, settled in Majhanpura in the 18th Century, and we belonged to the 9th generation, recording ca 235 years of time span (CE 17151950) (for details see, Singh 2013, pp. 41-42).

RBS was born on 03 February 1955 Thursday: Magha Shukla 11th Vikrama Samvata 2012 [five years younger than me] in the home itself, and was nurtured by members of the jointfamily usual in such countryside. On the line of family traditions and taboos through the arrangements of the parents and relatives, R.B. Singh was married to Radha Singh on 24 June 1973, a homemaker and religious lady who sacrificed her life devotedly serving for the good causes of her husband. They have four children: three daughters and one son-all are settled. The first one, Anju Singh (b. 1976, daughter), $\mathrm{PhD}$ in geography on 'Environmental Implications of Metropolisation: A Case of Delhi Region' (2004, from the Banaras Hindu University, her father's alma mater) is specialised in urban, environmental studies and climatology, and serving as Associate Professor at Aditi College, University of Delhi. (Late) Manju Singh (b. 1980; d. 2014, daughter), had MS in Chemistry, Polytechnic Institute of NYU, Brooklyn, NY, USA (2006), and PhD in Nanobiotechnology at Genova University (Italy) and Marburg University (Germany) (2014); she died due to blood fusion. Manish Singh (b. 1982, son), PhD 2015 in biophysics, is serving as a postdoctoral researcher at CNRS, Institut de biologie physico-chimique at Paris, France; he is trained in Physics (Optics) and specialises in functional imaging and super-resolution microscopy. And Anu Singh Bisht (b. 1985, daughter) has been a Post-Doctoral Research Fellow (July 2014--July 2016) at the University of Technology of Troyes, Troyes, France; and currently working as Information System Analyst II, GEICO, Chevy Chase, Maryland, USA. Her research monograph is published in AGES Series of Geography, entitled Commercial Surfactants for Remediation: Mobilization of Trace Metals from Estuarine Sediment and Bioavailability (Springer Nature Pte Ltd, Singapore, 2019).

RBS was careless about his health and more involved in his image-making and trying to be unique and distinct as the tallest figure in Indian geography, which he succeeded in achieving to some extent, but he paid its price. Since the last eight years, RBS has been suffering from Nephrotic syndrome (damage of the kidneys' filtering system, resulting from removing too much protein from the blood), resulting in more dependency on strict dietary habits and regular dialysis. Resultantly he was admitted in a severe condition in the ICU in Jaipur Gold hospital, where passing two weeks, he departed from this world on 22 July 2021 at 03:50AM IST (that is, Thursday, Ashadha Shukla 13th Samvata 2078). We all family members, friends and students are 
thrown into the painful ditch of shock, sorrow, suffering and devastation; however, one has to accept this hard truth as the curse of destiny.

The serene environment of the Sarayu riverfront, the sacred groves and gardens in the surroundings, small monastery of a Vaishnavite saint in the vicinity and beautiful lush trees and shrubs in the surroundings, and also the allaround scattered green fertile fields - altogether made an environmental setting where innocent childhood mind of RBS developed deep attachment to the spirit of places and the village ecology that flourish and sustained throughout his life journey.

Having primary education up to 5 th grade in the village school, he had received education up to 8th grade in a junior high school at Revelganj (now named Gautam Sthan, at a distance of 5$\mathrm{km}$ ), followed with his further studies (9th to 12th grade: four years) in the Rejendra College at Chhapra, lying $15-\mathrm{km}$ from the native village. Together with other classmates, he was attending the college by using local bus service, or some time with the help of some friends using bicycle. This was an arduous journey, however, he learnt the field observations and importance of walking and travelling in the countryside, which helped make his future journey easy and enjoyable. In 1973 he passed his 12th grade (see Table 3), under the guardianship of his teacher Professor B.L. Sinha, who taught him the first geography lesson. That was the crucial period when the family was in favour of getting RBS to join a job and support the family's sustenance. However, with support, encouragement and assurances for all the supports from his elder brother (myself; see Figure 1), he followed him, and in the first week of July 1973, together with me, he took the train to his destination for making the future career at Banaras Hindu University, Varanasi.

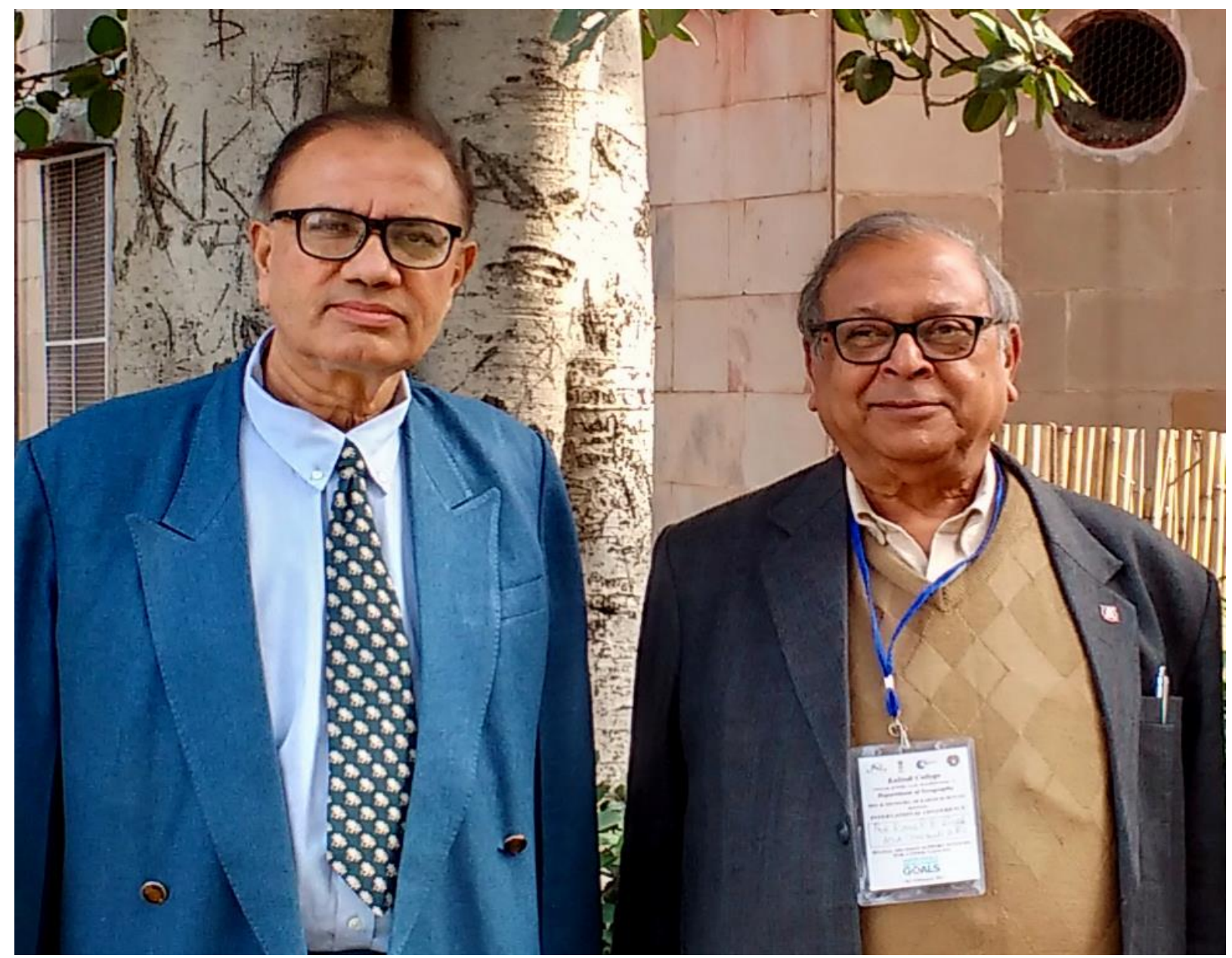

Figure 1: The two brothers: Professor R.B. Singh and Professor Rana P.B. Singh, Seminar at Delhi, 4 March 2017 


\begin{tabular}{|c|c|c|}
\hline & Year & Biobibliographical Landmarks and distinctions \\
\hline 1. & 1955 & 3 February, birth in a traditional farming family, Majhanpura, Bihar \\
\hline 2. & 1973 & Passed I.A.- 12th grade, Rajendra College, Chhapra, Bihar \\
\hline 3. & 1973 & 24 June 1973, married to Radha Singh \\
\hline 4. & 1975 & Passed B.A., Faculty of Arts, Banaras Hindu University, Varanasi. \\
\hline 5. & 1977 & Passed M.A. (Arts) Geography, ranked 1st, Banaras Hindu University \\
\hline 6. & 1979 & Diploma in Statistics, Dept. of Statistics, Banaras Hindu University \\
\hline 7. & 1981 & Awarded PhD in Geography, Banaras Hindu University, Varanasi \\
\hline 8. & 1983 & CSIR Pool Officer, Dept. of Geography, Banaras Hindu University \\
\hline 9. & 1985 & Lecturer in Geography, Delhi School of Economics, University of Delhi \\
\hline 10. & 1987 & $\begin{array}{l}\text { April } 1987 \text { to Sept. 2000, served as Provost (Acting), Warden and } \\
\text { Resident Tutor of the Gwyer Hall Hostel, University of Delhi. }\end{array}$ \\
\hline 11. & 1988 & UGC Research Scientist -B (Reader) at DSE, University of Delhi \\
\hline 12. & $1988-89$ & $\begin{array}{l}\text { October to April - UNEP-UNITAR Fellowship at Lausanne and Geneva, } \\
\text { Switzerland }\end{array}$ \\
\hline 13. & 1992 & $\begin{array}{l}\text { Elected as South Asian Representative in Managing Board of the } \\
\text { Commonwealth Geographical Bureau (1992-2000). }\end{array}$ \\
\hline 14. & 1996 & UGC Research Scientist - C (Professor level) at DSE, Delhi University \\
\hline 15. & 1998 & Sept.-Oct. Fellow as Asian Scholar, NIAS, Copenhagen, Denmark \\
\hline 16. & 2001 & $\begin{array}{l}\text { 2nd April, Monday: Chaitra Shukla 9th Samvata 2058: shifted to his } \\
\text { residence, Flat no. 143- Kadambari, Sector - 9, Rohini, Delhi }\end{array}$ \\
\hline 17. & 2002 & Professor of Geography, Delhi Sch. of Econ., University of Delhi \\
\hline 18. & $2002-10$ & $\begin{array}{l}\text { Elected Secretary General- Nat. Assoc. of Geographers India (NAGI); also } \\
\text { served earlier as Joint Secretary in } 2001 .\end{array}$ \\
\hline 19. & 2002-07 & Editor, Association of Geographical Studies, Delhi University. \\
\hline 20. & 2004-07 & $\begin{array}{l}\text { Elected Secretary, Hydrology Section, Asia-Oceania Geoscience Society, } \\
\text { Singapore. }\end{array}$ \\
\hline 21. & 2004 & $\begin{array}{l}\text { 15-20 Aug.: Member, INSA National Delegation to 30th IGC International } \\
\text { Geography Congress, Glasgow, U.K. }\end{array}$ \\
\hline 22. & 2006-09 & $\begin{array}{l}\text { Regional Promoter-South Asia, IGU Initiative Culture, Civilizations and } \\
\text { Human Development (Home of Geography, Italy). }\end{array}$ \\
\hline 23. & 2007-10 & $\begin{array}{l}\text { Nominated Special Representative-World Association of Soil and Water } \\
\text { Conservation. }\end{array}$ \\
\hline 24. & $2008-23$ & $\begin{array}{l}\text { Nominated Member-IUGG-IGU National Committee (4-terms), Indian } \\
\text { National Science Academy; served till his last breath on } 22 \text { July } 2021 .\end{array}$ \\
\hline 25. & 2008-12 & Vice-Chair-IGU Commission on Biogeography and Biodiversity \\
\hline 26. & 2008 & $\begin{array}{l}\text { 15-20 August: Leader, INSA National Delegation to 31st IGC International } \\
\text { Geography Congress, Tunis, Tunisia. }\end{array}$ \\
\hline 27. & $2010-13$ & Managing Editor- Nat. Assoc. of Geographers, India, Annals-NAGI. \\
\hline 28. & 2012 & $\begin{array}{l}\text { 26-30 Aug.: Leader, INSA National Delegation to 32nd IGC International } \\
\text { Geography Congress, Cologne, Germany. }\end{array}$ \\
\hline 29. & 2012-16 & Elected Vice President: International Geographical Union (IGU). \\
\hline 30. & $\begin{array}{l}2012 \\
\text { (4-times) }\end{array}$ & $\begin{array}{l}\text { Presentations: 25-27 April - Zhangjiajie, China; 21-23 May - Chiba, Japan; } \\
\text { 7-11 June - Harbin, China; 26-30 August- Cologne, Germany }\end{array}$ \\
\hline 31. & 2013-16 & Head, Department of Geography, DSE, University of Delhi. \\
\hline
\end{tabular}




\begin{tabular}{|c|c|c|}
\hline 32. & 2013-18 & Coordinator: UGC SAP DRS III, Dept. of Geography, Univ. of Delhi. \\
\hline 33. & 2013 & June-July- Research Fellowship: JSPS, Hiroshima, Japan. \\
\hline 34. & 2013 & 2-9 August- Kyoto, Japan; 1-3 December- Tokyo, Japan \\
\hline 35. & 2014 & 17-18 July- Tokyo, Japan; 18-22 August- Krakow, Poland \\
\hline 36. & 2014 & $\begin{array}{l}\text { Founding Series Editor: Advances in Geographical and Environmental } \\
\text { Sciences (ISSN: 2198-3542), Springer Nature Pte Ltd., Singapore; till } 2021 \\
\text { total } 23 \text { vols. published, out of these } 14 \text { are his co-edited. }\end{array}$ \\
\hline 37. & $\begin{array}{l}2015 \\
\text { (6-times) }\end{array}$ & $\begin{array}{l}\text { 23-25 February- Copenhagen, Denmark; 6-9 March- Kyoto, Japan; 20-22 } \\
\text { April- AAG Meet Chicago; 26-30 August- Moscow, Russia; 9-12 October- } \\
\text { Shanghai, China; November } 30 \text { Nov.- } 2 \text { Dec. - Kyoto, Japan. }\end{array}$ \\
\hline 38. & $\begin{array}{l}2016 \\
\text { (3-times) }\end{array}$ & $\begin{array}{l}\text { 27-29 January- Geneva, Switzerland; } 28 \text { Feb.- } 1 \text { March- Cape Town, S. } \\
\text { Africa; 7-9 June- Macau, China }\end{array}$ \\
\hline 39. & 2016 & $\begin{array}{l}\text { Re-elected Vice President: International Geographical Union (IGU) for } \\
\text { second term (2016-2018). }\end{array}$ \\
\hline 40. & 2016 & $\begin{array}{l}28 \text { Feb.- } 2 \text { March: as Panellist in the IAP-Global Network of Science } \\
\text { Academies in Times of Disaster Emergencies in South Africa. }\end{array}$ \\
\hline 41. & 2016 & $\begin{array}{l}\text { 21-25Aug.: Leader, INSA National Delegation to 33rd IGC International } \\
\text { Geography Congress, Beijing, China }\end{array}$ \\
\hline 42. & 2017 & 23-25 November- Tokyo, Japan \\
\hline 43. & 2017 & $\begin{array}{l}\text { July } 2017 \text { - till July 2021: (i) Chair-Research Council- CSIR Central Food } \\
\text { Technological Research Institute (CFTRI), Govt. India, Mysore; (ii) } \\
\text { Member-Research Council-CSIR-Central Institute for Medicinal and } \\
\text { Aromatic Plants (CIMAP), Government of India, Lucknow. }\end{array}$ \\
\hline 44. & 2018 & Nominated as Secretary General \& Treasurer, IGU, term: 2018-2022. \\
\hline 45. & 2018-19 & $\begin{array}{l}\text { Chair, Task Force, Landslides Awareness, National Disaster Management } \\
\text { Authority, Government of India. }\end{array}$ \\
\hline 46. & $2019-20$ & $\begin{array}{l}\text { Elected President of the Earth System Science Section of the Indian } \\
\text { Science Congress Association. }\end{array}$ \\
\hline 47. & $2019-20$ & $\begin{array}{l}\text { (II-term) Head, Dept. of Geography, DSE, University of Delhi: } \\
\text { Feb. } 2019 \text { - till } 29 \text { Feb. } 2020 \text { (the day of retirement). }\end{array}$ \\
\hline 48. & 2020 & $\begin{array}{l}\text { Nominated as a member of the NITI Aayog, Government of India for } \\
\text { preparing Vision India- } 2035 .\end{array}$ \\
\hline 49. & 2020 & 29 Feb. (at 65-years age) superannuated from DSE, Univ. of Delhi. \\
\hline$\overline{50 .}$ & 2021 & $\begin{array}{l}22 \text { July: 03:50AM, death by kidney failure in Jaipur Gold Hospital, New } \\
\text { Delhi: "End of the Era of RBS" }\end{array}$ \\
\hline 51. & 2022 (?) & $\begin{array}{l}\text { 18-22 July: IGU 100th Anniversary Congress, Paris, France; INSA Progress } \\
\text { in Geography, India, 2016-2022 as a memorial to R.B. Singh -? }\end{array}$ \\
\hline
\end{tabular}

\section{Formative Platform of Making}

In the second week of July 1973, RBS was admitted to the B.A. course in the Faculty of Arts at Banaras Hindu University, having three subjects to study as the system prevailed during that time. He had chosen geography, ancient Indian history \& culture, and English literature. After living with his elder brother in the Aiyar Hostel (Room. No. 19) for about ten days, he was allotted a room in the Birla Hostel (No. 73); of course, he was taking all his meals in the canteen of Aiyar Hostel under the patronage of myself. Regularly, he had discourse and dialogues with me after dinner that encouraged and helped him create his own world of understanding and geographical vision for the future. He had passed through this academic journey smoothly with sincerity, resulting in accomplishing First Division in his B.A. with distinction in the subject of geography. This helped him get admission easily 
in M.A. in Geography at Banaras Hindu University in 1975, with the support of then Head of the Department, Professor R.L. Singh (1917-2001), known as Dean and Doyen of Modern Geography in India. He was taught by such senior and learned geography masters, who had also taught me (now all of them have passed away), like Professors R.L. Singh, S.L. Kayastha, A.S. Jauhari, Kashi N. Singh, Narmdeshwar Prasad, Vijai Ram Singh, and of course, myself (as Senior fellow, I was teaching classes); most of these teachers have taught him in his bachelor studies too. The training here was slightly different from the contemporary geography centres involved in making a geographer as part of academic pigeonholing; instead, it opened the mind to put geography anywhere and create that beautiful. Here for the first time, he learned the use of technology and technocratic approach in understanding landscape and culture; however, he finally put himself into the ocean of empiricism and technocratic narration. What is in the contemporary world is the common scenario. In this realm, the theoretical construction and insightful interpretations become weaker, and pre-determined ideology and pontification become common. In the passage of time, our paths got parallel running: RBS followed through the lenses of 'Remote Sensing \& GIS', and I followed the path of 'Intimate Sensing \& Deep Ecology'.

I was a U.G.C. senior research fellow that helped me to support RBS for all sorts of the financial requirements, including fees, meals and refreshments, educational facilities and personal needs for livelihood, and also some extra pocket money to fulfil his miscellaneous purposes, etc.; no way the family could afford to support financially even at marginal level. It was during this period RBS came in close contact with friends interested in social activism and politics, resulting in his involvement in students' politics. Thanks to his sense of devotion and dependency with trust in me as 'overall guardian' and another senior student in economics, Shri Haribansh (presently Deputy Chairman Rajya Sabha- 'Council of States' in the Parliament, Government of India, New Delhi) that convinced his mind to give priority to higher studies avoiding active part in politics. RBS always used to give credit to me for my life-long walk on the geographic pathway. This helped him in a much better way; resultantly, he had passed M.A. (1977) in geography (Arts), securing the first position with the highest marks. For his master class dissertation, at my suggestion, RBS took the topic to understand and expose the space, time and culture of our native village within the frame of rural ecology, which in course of following about three years we worked together to develop a research monograph, under the patronage of IGU Working Group on 'Transformation of Rural Habitat in Developing Counties', under the chairpersonship of Professor R.L. Singh, and was published in 1981. This was our first joint publication as a memorial tribute to our native village, where the family genealogy and linked tree models, socioeconomic structure, land occupancy, the religious landscapes, caste ranking, and such related issues are discussed within the purview of my own doctoral research (see, Singh 1977). Let me cite the reminiscences of Haribansh, which explicitly narrates RBS's overall personality:

Prof. R.B. Singh, for us 'Rambabu', was among my personal family friends, as both belong to the same clan. The untimely and sudden news of his sad demise was unexpected. We started the journey of life together from Birla Hostel of Banaras Hindu University in 1973, and that intimacy, mutual harmony, respect for each other that remained till the end in 2021. During our student days, with whom we shared studies, deep interest in social questions and dreams and resolutions of youthful days. Rambabu was very sincere, affectionate and full of compassion and affection towards anyone. But there was another strong reason for our intensity. It was through Rambabu that I met 'Rana Bhaiya' (Prof. Rana P.B. Singh), his elder brother, who lived in Aiyer hostel in those days, and was known in the university as a very 
brilliant, talented, hardworking research scholar. But Rana Bhaiya's generous nature, affection and affinity had created a huge world of younger brothers and admirers, in which I was also one. My coming and going to Delhi was frequent. For this reason, contact with Rambabu remained even after leaving the university. We met quite frequently. We had the same affection, belonging and connection, which initiated about 48-years. Because we would have been proud of Rambabu's international achievements, I would have always been aware of Bhaiya's extraordinary creative works. Rambabu had an impact on my personal life as a friend. His spontaneity, innocence and uniqueness in his field have always been a matter of pride for me. Also, Rana Bhaiya's extraordinary personality, achievement, creative work and deep spiritual and philosophical vision of life, passion for studies made a deep impact on Rambabu and me from the student life, and alive even today. That's why when I got the news of Rambabu's departure, I was shocked and stunned, feeling that the world of personal life has become deserted". - Shri Haribansh (personal letter, New Delhi, 30 August 2021).

Possession of good marks and his devotion to study resulted in getting the U.G.C. Junior Fellow award for the Ph.D. research. RBS was registered as doctoral student in July 1977 under the supervision of Professor S.L. Kayastha (19242018) on the topic-Geographical Dimensions of Integrated Rural Development: A Study of Siwan District, and was awarded the degree in 1981. This dissertation in revised form was published under the name, Geography of Rural Development (1986, New Delhi). During his research period, he received a Diploma in Statistics from Banaras Hindu University in 1979, which helped him incorporate statistical analysis in his dissertation. After the passage of time in
1982 he joined as CSIR Pool Officer, Department of Geography, Banaras Hindu University, and continued till August 1985, when he was selected as Lecturer (Assistant Professor) in the Department of Geography, Delhi School of Economics, the University of Delhi (cf. Table 3).

\section{Settling Down in the University of Delhi and Achievements There}

In August 1985, RBS had joined the University of Delhi, and the third phase of his life journey started; indeed, Delhi served as the like axis mundi or the epi-centre. Only the last two years, he spent on a rented accommodation. He shifted to the Gwyer Hall in April 1987 and continued there till September 2000, serving in the varying capacities of Resident Tutor, Warden and Provost (Acting) of the Gwyer Hall Hostel, University of Delhi. While associated with the Department of Geography, Delhi School of Economics, he had served and hold several positions, including (i) Vice- President, International Geographical Union (IGU), see Figure 2; (ii) Editor, Springer Nature Series Advances in Geographical and Environmental Sciences, 2014-2021 and published 25 volumes; (iii) Representing IAP-Global Network of Science Academies on Disaster Risk Reduction and UN Sc. \& Tech Conf. on Sendai Framework of DRR; (iv) Awarded with JSPS Research Fellowship, Japan in 2013; (v) Associate Faculty, Global Earth System Governance Project of ESSP, The Netherlands since 2008; (vi) Vice-Chair, IGU Commission on 'Biogeography and Biodiversity' (2008-12); (vii) Special Representative-World Association of Soil and Water Conservation; (vi) South Asian Representative in Commonwealth Geographical Bureau (1992-2000); and (vi) Full Member of IGU Commissions (1988- 2008) (for details of chronology, see Table 3 ).

His professional services, and membership to scientific committees (see, Table 1), included: Tutor and Provost, Gwyer Hall, University of Delhi (1987-2000); Secretary General of the National Association of Geographers, India, (NAGI) (2001-11), and Managing Editor of its Journal-Annals of NAGI (2010-13); Member, IUGG-IGU National Committee of the INSA (2008-22); Member and Leader, INSA National 
Delegation to IGU International Geography Congresses, Tunis (2008), Cologne (2012), and Beijing (2016); Nominated Member, Curriculum Development for Geo-informatics jointly nominated by UGC and Department of Space, Govt. of India; President, Geography Section, Indian Academy of Social Sciences; President of the Earth System Science Section of the Indian Science Congress Association (2019-20); HeadDepartment of Geography, Delhi University (two terms, 2013-2016 and 2019-20); Nominated, the NITI Aayog, Govt. of India for preparing Vision India- 2035 (2020); and Member, Study Group for Preparation of NCR Plan-2021.

The department of geography had provided him with a solid and potential platform for operating several of the projects, sponsored by national and international institutions, started from 1994 and coming close to 2014 (see, Table 1).

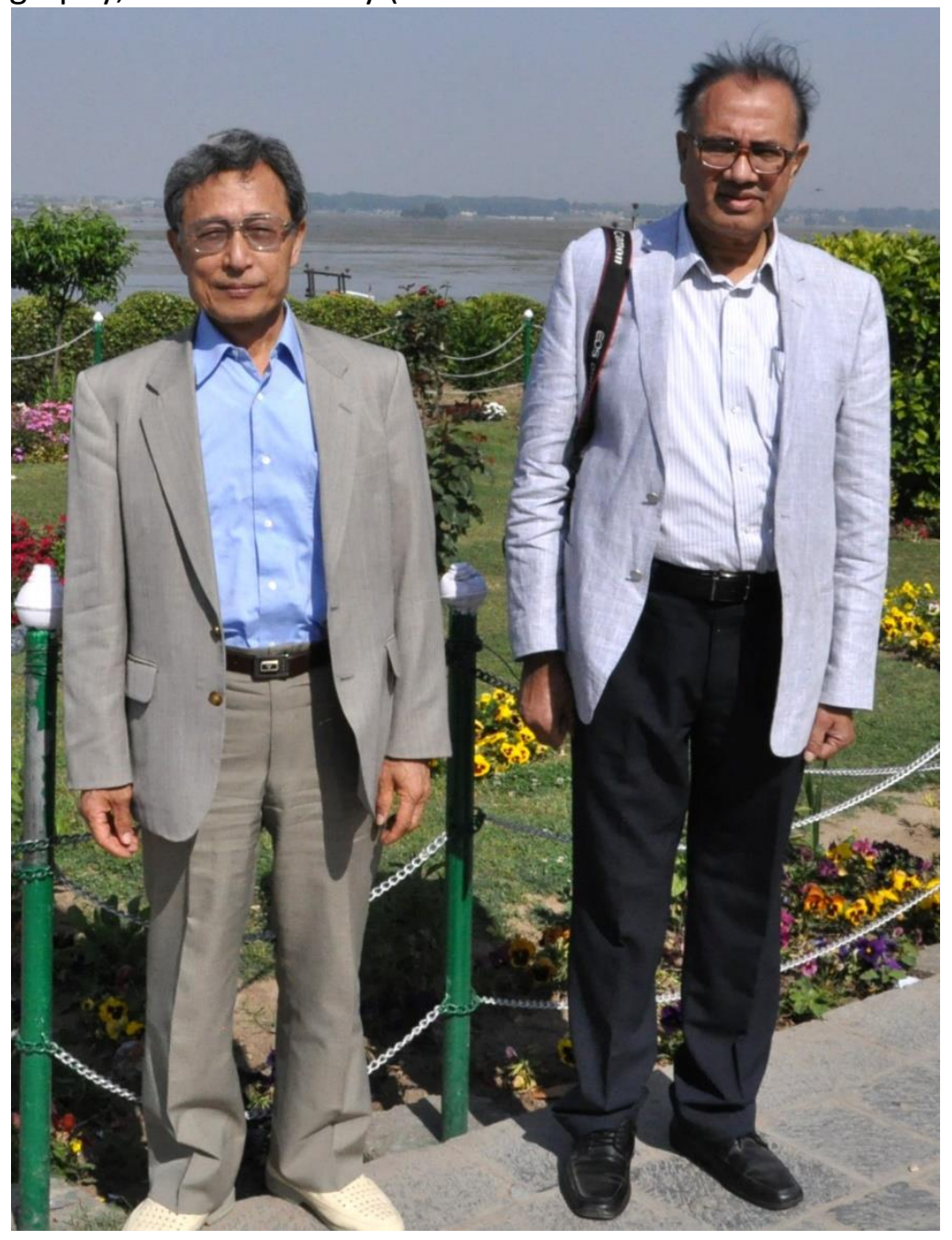

Figure 2: Professor Yukio Himiyama (IGU President) and Professor R.B. Singh (IGU Vice President), IGU-India Conference at Srinagar, India, 6 June 2014

\section{Publications: Variety, Distinctive and Reports}

Professor R.B. Singh had to his credit 16 books, 40 edited research volumes and around 260 research papers (see, Table 2) published in national and international journals (that is, Remote Sensing, Remote Sensing, Climate Dynamics, Current Science, Singapore Jl. of Tropical Geography, Energies, Agriculture, Theoretical and Applied Climatology, Physical
Geography, Environmental Science and Policy, Ecosystem and Environment, Advances in Meteorology, Hydrological Processes, Mountain Research and Development, Journal of Mountain Science, Climate, Frontiers in Environmental Science, Advances in Earth Science, Advances in Limnology, European Jl. of Geography, Asian Geographer, Environmental Economics, Cities and Health, Tourism Recreation Research). He was Special Guest 
Editor of the journals like Sustainability, Advances in Meteorology, Physics and Chemistry of the Earth, and NAM Today. He was on the Editorial Committee of Jl. of Mountain Science.

The gamut of publications by R.B. Singh consists of variety and distinct topics, crossing all the traditional border and themes of geography, and under different categories, which include (with a code and Table numbers, T): T-4 Books; T-5 Edited Volumes; T-6 Papers- Peer Reviewed; T-7 Papers in Indian Journals/ Books; T-8 Papers in Foreign Books \& Proceedings; T-9 Papers in Indian Books and Proceedings (see, Table 2). Altogether themes and subject matter of his publications could be broadly categorized under 13 categories, viz. Environmental Studies, Geoecology; Land resources, Land use/ Land cover; Water issues, Hydrology; Disaster, Natural Hazard; Quality of Life, Livelihood; Climatic Change, Air Pollution study; Urban Environment, health, wellbeing; SDGs, Environmental monitoring; Geography, Development Studies Rural and Urban; Mountain studies, Forestry, Tourism; RS, GIS, Recent trends appraisal; Regional Science \& SDGs; and INSA Geography Report, \& related (see, Table 2). The six categories of his publication (see, Tables 4 to 9, and Appendix: 1) are appraised here in short.

List of the R.B. Singh's books (16) to be classified into three categories, that is, (i) independent, consisting of two such books (research monographs), of them is his memorial lecture, a small piece on "Urban Sustainability, Health and Wellbeing and Disaster Risk Reduction" (2020), and another one his revised doctoral dissertation on Geography of Rural Development: a case study of Siwan district, Bihar (1986). Three other categories included are report-based books (5), co-authored books (4), and the revised doctoral dissertations of his students published as co-authored books (5) (see Table 4).

He was actively involved in preparing a huge mass of collected thematic papers in the form of anthologies; this list covers 40 publications from 1990 through 2021. This may be broadly categorised into three types, viz. self-edited (20), co-edited (7), and multi-editors' volume (13); all under the ten broad themes. Of course, among the 40 books, 29 books covered the four thematic groups, that is, Environmental Studies, Geoecology; Land resources, Land use/ Land cover; Climatic Change, Biospheric study; and SDGs, Environmental Monitoring (see, Table 5).

The list of research papers published in the peerreviewed journal and research series reached 64 (during 1979-2021, see, Table 6), covering eleven themes. Out of theme papers only 12 are independent, and the rest 52 are co-authored; the major themes were three: Water issues, Hydrology; Climatic Change, Air Pollution study; and Mountain studies, Forestry, Tourism, covering 38 entries. The follow-up group of papers refer to 'papers published in Indian Journals/books' during 1980-2020, counting to 62 (see Table 7), again to be classified into two: individual (23), and co-authored (39). These entries broadly covered the four thematic groups (enumerating 39 papers), viz. Land resources, Land use/ Land cover; Water issues, Hydrology; Disaster, Natural Hazard; and RS, GIS, Recent trends appraisal (see, Table 7).

The papers published in international anthologies and proceedings reached 58 , and as usual categorised into two: individual (20) and co-authored (37). Most individual papers are like encyclopaedical entries or popular descriptions/notes on a theme or based on reports. The primary focus covered three categories: Land resources, Land use/ Land cover (13), Mountain studies, Forestry, Tourism (9), and SDGs, Environmental monitoring (7) (see Table 8). The last group of papers covers 'papers in Indian Books and Proceedings' (1980-2022), covering 76 entries, categorised into two: individual (21) and co-authored (55); and discussed the two broad themes, that is, Mountain studies, Forestry, Tourism (20), and Disaster, Natural Hazard (14) (see, Table 9). 


\begin{tabular}{|c|c|c|c|c|c|}
\hline Se & Broad Theme & Independent & $\begin{array}{l}\text { Report-based } \\
\text { Book }\end{array}$ & Co-authored & $\begin{array}{l}\text { Co- } \\
\text { authored, } \\
\text { rev. PhD }\end{array}$ \\
\hline 1. & Environmental Studies, Geoecology & -- & -- & -- & 1 \\
\hline 2. & Disaster monitoring, Natural Hazard & -- & 2 & -- & 1 \\
\hline 3. & Climatic Change, Biospheric study & -- & -- & 1 & 2 \\
\hline 4. & $\begin{array}{l}\text { Urban Environment, health, } \\
\text { wellbeing }\end{array}$ & -- & -- & 1 & -- \\
\hline 5. & SDGs, Environment, Herbal plants & $1^{*}$ & & 1 & 1 \\
\hline 6. & Rural development (district level) & $1^{+}$ & & 1 & -- \\
\hline \multirow[t]{4}{*}{7.} & Assessment Report based book & -- & 3 & -- & -- \\
\hline & TOTAL $\quad$ (16) & 2 & 5 & 4 & 5 \\
\hline & \multicolumn{5}{|c|}{ * Based on a lecture (R.N. Dubey Foundation, Allahabad, 80-pp., 2015). } \\
\hline & \multicolumn{5}{|c|}{ + Revised own doctoral thesis, Banaras Hindu University, published in 1986.} \\
\hline
\end{tabular}

\begin{tabular}{|c|c|c|c|c|c|}
\hline $\mathrm{Se}$ & Broad Theme & $\begin{array}{l}\text { Self- } \\
\text { edited }\end{array}$ & Co-edited & $\begin{array}{l}\text { Multi- } \\
\text { editors }\end{array}$ & Total \\
\hline 1. & Environmental Studies, Geoecology & 5 & 1 & 3 & 9 \\
\hline 2. & Land resources, Landuse/ Landcover & 2 & 2 & 3 & 7 \\
\hline 3. & Water issues, Hydrology, Watershed & -- & 1 & -- & 1 \\
\hline 4. & Disaster, Hazard & 2 & -- & - & 2 \\
\hline 5. & Quality of Life & -- & 1 & -- & 1 \\
\hline 6. & Climatic Change, Biospheric study & 2 & -- & 4 & 6 \\
\hline 7. & Urban Environment, health, wellbeing & 1 & -- & -- & 1 \\
\hline 8. & SDGs, Environmental monitoring & 4 & 2 & 1 & 7 \\
\hline 9. & Regional Science \& SDGs & -- & -- & 2 & 2 \\
\hline 10. & INSA Geography Report, \& related & 4 & -- & -- & 4 \\
\hline-- & Total $(40)$ & 20 & 7 & 13 & 40 \\
\hline
\end{tabular}

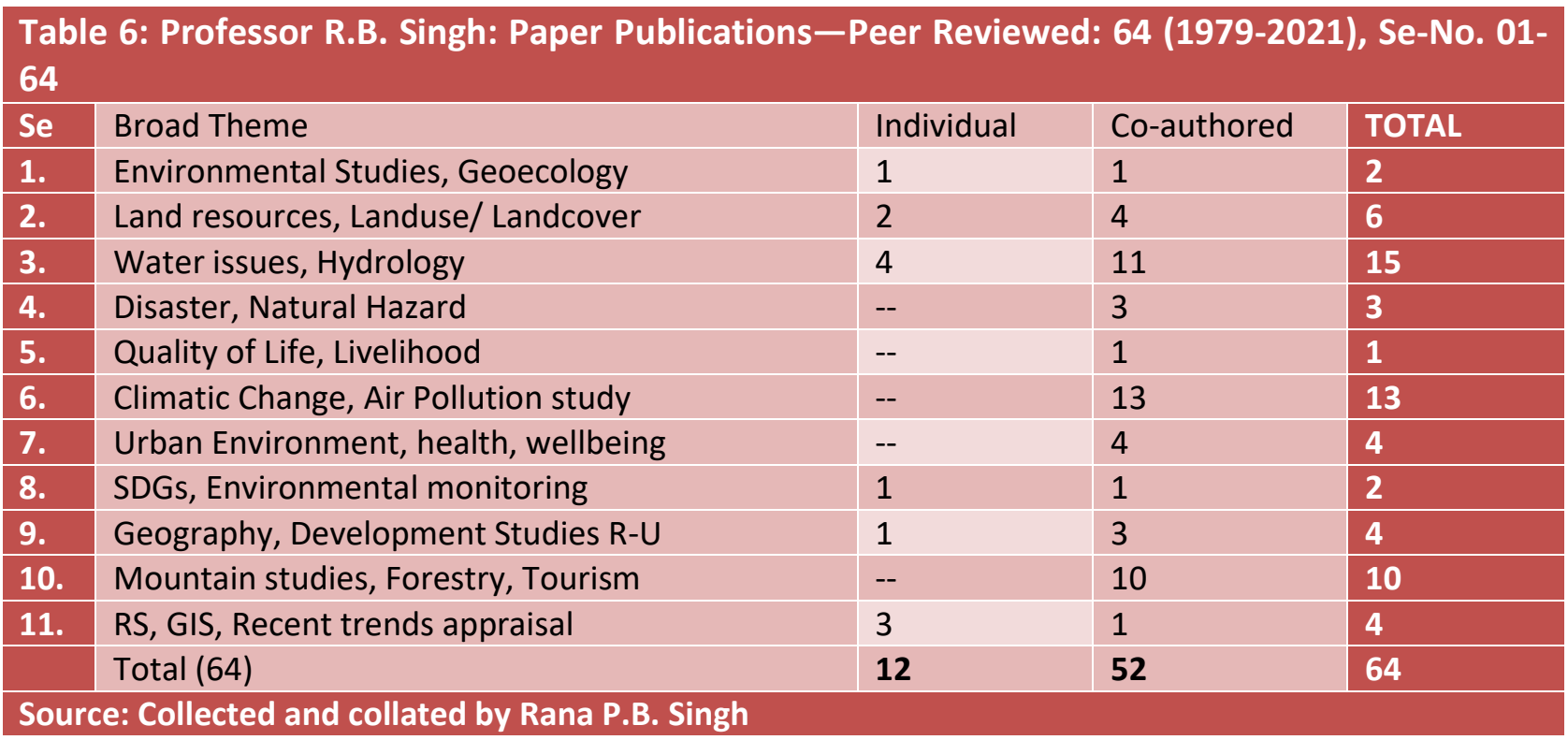




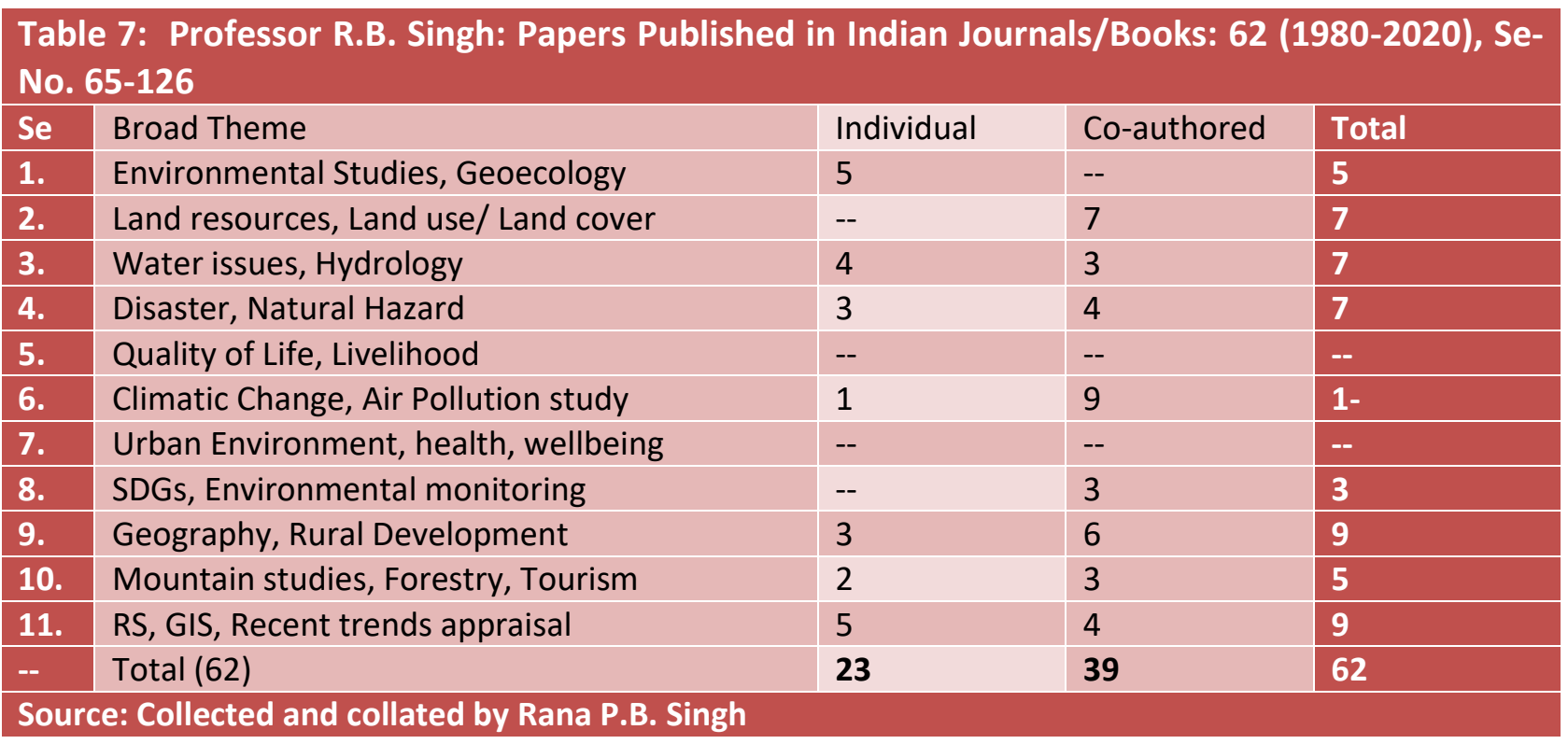

\begin{tabular}{|c|c|c|c|c|}
\hline Se & Broad Theme & Individual & Co-authored & Total \\
\hline 1. & Environmental Studies, Geoecology & 2 & 3 & 5 \\
\hline 2. & Land resources, Landuse/ Landcover & 5 & 8 & 13 \\
\hline 3. & Water issues, Hydrology & 1 & 3 & 4 \\
\hline 4. & Disaster, Natural Hazard & 1 & 5 & 6 \\
\hline 5. & Quality of Life, Livelihood & -- & 1 & 1 \\
\hline 6. & Climatic Change, Air Pollution study & -- & 4 & 4 \\
\hline 7. & Urban Environment, health, wellbeing & -- & -- & -- \\
\hline 8. & SDGs, Environmental monitoring & 4 & 3 & 7 \\
\hline 9. & Geography, Rural Development & 2 & 4 & 6 \\
\hline 10. & Mountain studies, Forestry, Tourism & 2 & 7 & 9 \\
\hline \multirow[t]{2}{*}{11.} & RS, GIS, Recent trends appraisal & 3 & -- & 3 \\
\hline & Total (58) & 20 & 38 & 58 \\
\hline
\end{tabular}




\begin{tabular}{|c|c|c|c|c|}
\hline Se & Broad Theme & Individual & Co-authored & Total \\
\hline 1. & Environmental Studies, Geoecology & 2 & 1 & 3 \\
\hline 2. & Land resources, Landuse/ Landcover & 3 & 4 & 7 \\
\hline 3. & Water issues, Hydrology & -- & 5 & 5 \\
\hline 4. & Disaster, Natural Hazard & 4 & 10 & 14 \\
\hline 5. & Quality of Life, Livelihood & -- & 5 & 5 \\
\hline 6. & Climatic Change, Air Pollution study & -- & 2 & 2 \\
\hline 7. & Urban Environment, health, wellbeing & -- & 1 & 1 \\
\hline 8. & SDGs, Environmental monitoring & -- & 4 & 4 \\
\hline 9. & Geography, Rural Development & 2 & 7 & 9 \\
\hline 10. & Mountain studies, Forestry, Tourism & 7 & 13 & 20 \\
\hline \multirow[t]{2}{*}{11.} & RS, GIS, Recent trends appraisal & 3 & 3 & 6 \\
\hline & Total (76) & 21 & 55 & 76 \\
\hline
\end{tabular}

Supervision of Doctoral \& M.Phil Dissertations

Professor R.B. Singh was an outstanding mentor, guide, and life-long advisor to his students. In his 29 years career of supervising PhD and MPhil (1992-2020), like his excellent mass of papers, he had guided 39 doctoral dissertations and 81 masters of philosophy (see, Table 10, and Appendix: 2). Half of the doctoral dissertations dealt with Environmental Studies, Geoecology (11), and Land resources, Land use/ Land cover (7). The predominance of these topics was associated with the similar projects where these students worked and, on those themes, submitted their dissertations. Thus, it served the dual benefit: completing the projects and awarding the degree to the associated students. In the case of MPhil's dissertations, the major topics covered include four broad themes, viz. Climatic Change, Biospheric study (16); Disaster, Natural Hazard (11); Mountain studies, Forestry and related issues (11); and Environmental Studies, Geoecology (10)-altogether these covers around 60 per cent of the total.

\begin{tabular}{|c|c|c|c|}
\hline Se & Broad Theme & $\begin{array}{l}\text { No. of PhD } \\
1992--2020\end{array}$ & $\begin{array}{l}\text { No. of MPhil } \\
1987--2020\end{array}$ \\
\hline 1. & Environmental Studies, Geoecology & 11 & 10 \\
\hline 2. & Land resources, Land use/ Land cover & 7 & 6 \\
\hline 3. & Water issues, Hydrology, Watershed & 4 & 8 \\
\hline 4. & Disaster, Natural Hazard & 4 & 11 \\
\hline 5. & Quality of Life, well being & 3 & 4 \\
\hline 6. & Climatic Change, Biospheric study & 3 & 16 \\
\hline 7. & Urban Environment, health, wellbeing & 3 & 5 \\
\hline 8. & SDGs, Environmental monitoring & 3 & 6 \\
\hline 9. & Human geography, Rural development & 1 & 4 \\
\hline \multirow[t]{3}{*}{10.} & Mountain studies, Forestry and related issues & -- & 11 \\
\hline & Total & 39 & 81 \\
\hline & \multicolumn{3}{|c|}{$\begin{array}{l}\S \text { PhD - addition, Co-supervised dissertations: Urban health 2, Organic Farming 1, Climatic } \\
\text { variability 1; Total: } 4 \text {. Altogether: } 43 .\end{array}$} \\
\hline
\end{tabular}

Source: Collected and collated by Rana P.B. Singh; see Appendix: 2 


\section{Major Projects and Presentations Abroad}

Professor R.B. Singh, as a Project Director/Principal Investigator had undertaken collaborative major research projects on Livelihood Security in Changing Socio-Economic Environment in Himachal Pradesh, India (20122016) collaborated with the University of Turku, Finland, Shastri Applied Research Project (SHARP) on Role of Public, Private and Civil Sectors in Sustainable Environment Management (2003-2005) collaborated with University of Manitoba and the University of Winnipeg, Winnipeg, Canada, ICSSR - IndoDutch Programme on Alternative in Development (IDPAD) on Environmental Implications and its Socio-Economic Implications in Rural-Urban Fringe of Delhi -University of Delhi \& University of Groningen, The Netherlands. (1997-2002), CIDA-SICI Partnership Project-II on Urban Development and Environmental Impacts in Mountain Context, University of Delhi \& University of Manitoba, Canada (1998-2002), DFID Research Project on Enhancing Food Chain Integrity: Pollution Impact on Vegetable System (2000-2) in Peri-Urban Areas, Collaboration with Imperial College, London, UK, CIDA-SICI Partnership Project-I on Sustainable Development of Mountain Environment in India and Canada, University of Delhi \& University of Manitoba, Canada (19941997), Ministry of Agriculture Project for Preparation of Perspective Plan for Land Resources in N. Zone, India (1994) (see, Table 1). For discussion and discourses on the progress and assessment of these projects, together with IGU meets, he had presented his researches across more than 40 countries, including Armenia, Australia, Bhutan, Brazil, Canada, China, Czech Rep., Denmark, Egypt, Finland, France, Georgia, Germany, Indonesia, Ireland, Israel, Italy, Japan, Kyrgyz Republic, Luxembourg, Mongolia, Malaysia, Mexico, Nepal, Netherlands, Norway, Poland, Russia, Singapore, South Africa, Sri Lanka, South Korea, Spain, Sweden, Switzerland, Taiwan, Thailand, Tunisia, Turkey and UK, and the USA (see, Roy 2021).

\section{The Role, Contribution and Vision in the International Geographical Union (IGU)}

Since 1984, IGU Paris Congress, R.B. Singh had attended all the main Congresses and most of the IGU Regional Conferences and had been actively participating in the academic programs of various IGU Commissions and Working Groups. His previous assignments were: Full Member in the IGU Commissions/Study Groups, viz. Mountain Geoecology and Resource Management (1988-1992), Development Issues in Marginal Lands (1992-1996), Land Use and Cover Change (1996-2004) and Biogeography and Biodiversity (2004-2008); Vice-Chair of the IGU Commission on Biogeography and Biodiversity (2008-2012).

Professor Singh was the Vice-President, International Geographical Union (IGU) since 2012 and was elected again for the second consecutive term (2016-18). And, recently, he was elected as first Indian and second Asian, being Secretary-General and Treasurer of the International Geographical Union for the term 2018-2022. As a geographer, he firmly believed in demonstrating interdisciplinary orientation and professionalism in using geographical knowledge and skills. In 1991, he had also organised an interdisciplinary IGU Seminar at Delhi in which four IGU Commissions/ Groups participated. Being a member of the executive committee of the Indian National Science Association (INSA), he got the chance to serve as head of the Indian Delegation to IGU Congress held at Tunis (2008), Cologne (2012), and Paris (2016), where he had raised voices for special concerns to South Asia.

He had also taken the initiative to start a 2-yr alternate IGU-India Conference, already four such meets held at different centres and were attended by selected IGU EC Members and its associated. Many of the proceedings of such conferences were published in his own series editorship under Springer Nature. This was an attempt at his own image-making, making IGU related conferences at the national level. In a way, this was an attempt to Indianise the IGU in projecting the image of Indian geography at a global level, of course, succeeded only 
marginally, primarily due to Indian politics and regionalism.

In 2015, Professor R.B. Singh had played an instrumental role as the then Vice-President of the IGU Executive Committee meeting held during the IGU Regional Conference at Moscow, Russia, 17-22 August 2015 (see Figure 3) to establish a 'Taskforce' dedicated to stimulating activities of young and early career geographers in IGU. Through a global call of applications, the Steering Committee was formed. This newly established IGU 'Taskforce for Young and Early Career Geographers' (TYECG) was launched at the 33rd IGU Congress in Beijing, China, on 22nd August 2016, and Dr. Gaurav Sikka (Darbhanga, Bihar, India) was elected as the Secretary and Treasurer, and Dr. Komalirani Yenneti (now, University of Wolverhampton, UK) as the Chair of the Taskforce. The TYECG aims to promote career development for early career geographers through mentoring, training and competitions; stimulate interdisciplinary, international and inter-generational research conversations between geographers and acknowledge and elevate the achievements of early-career geographers in the Global North and South. This initiative and creation of Professor R.B. Singh will be a role model in making geography the serving catalyst for society. At this juncture, the first such initiative was taken to encourage and provide a publication platform for outstanding young and early career geographers. That is how a special issue guest edited by Gaurav Sikka, Komalirani Yenneti, R.B. Singh and V.S. Tikunov, themed as "Geospatiality and Sustainable Development Goals" was published with Geography, Environment, Sustainability (GES) journal-the official journal of Russian Geographical Society (Sikka et al., 2021).

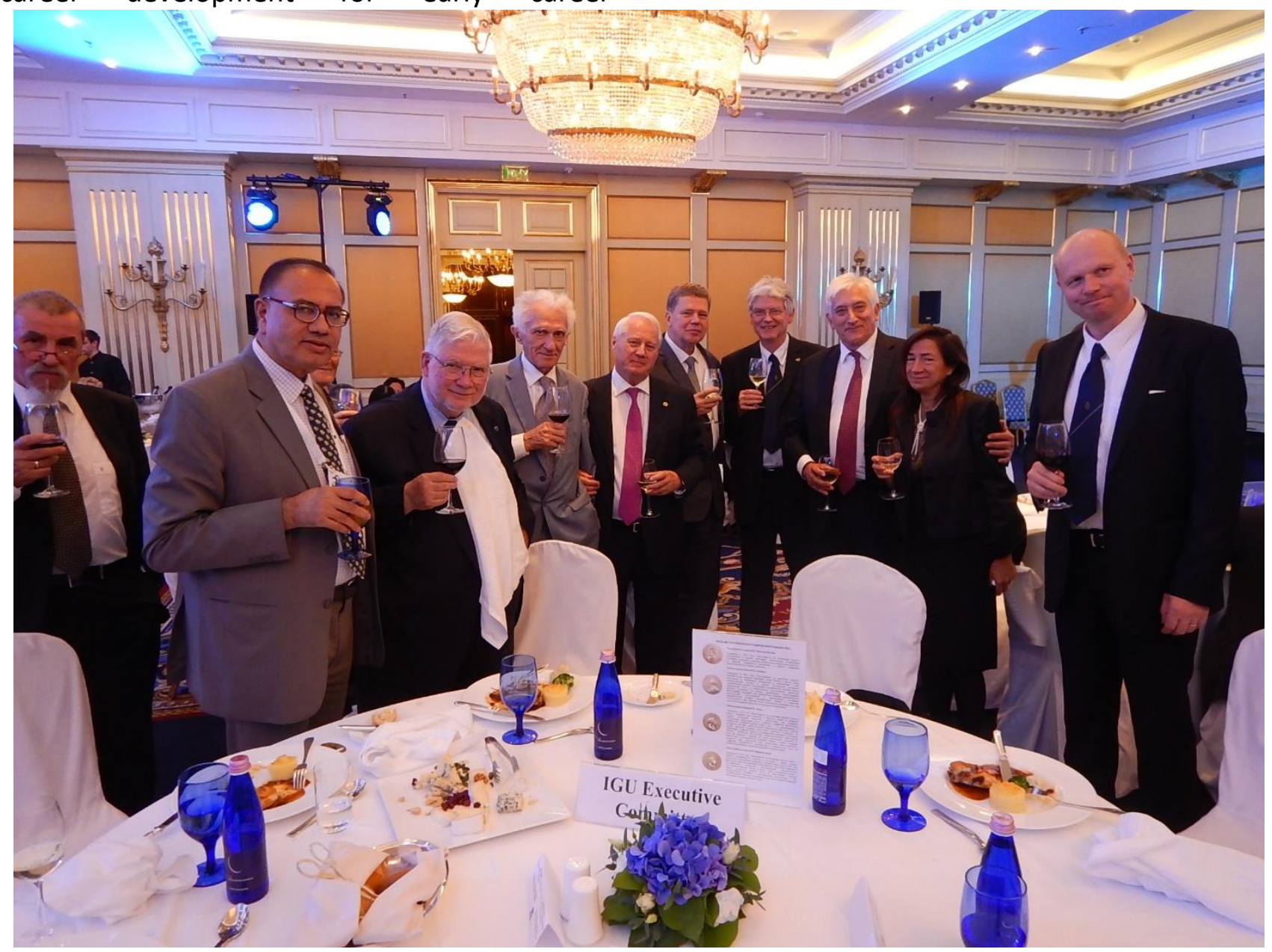

Figure 3: IGU Regional Congress, 22 August 2015, Moscow, Russia: IGU Executive Committee Meet. 
Professor R.B. Singh, till last breath, was on the Chair, Research Council, CSIR-Central Food Technological Research Institute, Mysore; Member-Research Council- CSIR-Central Institute of Medicinal and Aromatic Plants, Lucknow; Member of International Science Council (earlier ICSU) Scientific CommitteeHealth and Wellbeing in Changing Urban Environment-System Analysis Approach since 2016. But, despite all his dignified positions, recognitions, networking and political links, he had not attempted to revive the existence of the Indian Council of Geographers, which was already abandoned since 1960, and never got affiliated to the government, like its counterparts, for example, Indian Council of Social Science Research (ICCR), Indian Council of Philosophical Research (ICPR), Indian Council of Historical Research (ICH), etc. This way Indian geography forum to date failed to have direct interlink to the government system. Similarly, one can also count his negligence (or in a way failure) in the formation of any institution, or even research society in India, like the progenitor of Indian Geography- Professor S.P. Chatterjee (1903-1989), Vice President (19601964), and subsequently President of IGU (19641968), who had developed National Atlas and Thematic Mapping Organization (NATMO), and also established Geographical Society of India, both at Kolkata.

However, Professor RB Singh had successfully mobilised and used his dignified position and international links to develop and enhance the following notable contributions, what he had visioned and proposed for his candidacy to ViceChairman and later as Secretary General of the IGU, which included: organizing annual IGU and IYGU events in South Asia for benefit to various cross sections of the society; initiating a Global Open Day for Geography at National Level, especially in developing countries with emphasis on interdisciplinary discourses and promoting joint research projects; promoting IGU as a platform for global understanding, contemporary concerns, prioritization and help in making policies and promotion of leadership; improving academic orientation of IGU through series of publications and start of new thematic publication series, while maintaining professional standards and the global ethics (e.g.) Advances in Geography and Environmental Science series under Springer Nature, which is already publishing since 2014); and developing and maintenance of close linkages with UNO and its major branches for promotion of the good causes of IGU. And, ( $v$ ) Accomplishing Science-Policy Interface (SPI) within IGU Regional Conferences and Congresses on one hand and National committees/Commissions on the other.

\section{Memorials and Messages from the IGU}

Here are a few (selected) reminiscences of the IGU senior associates:

I first came into contact with Professor R.B. Singh - I knew him affectionately as 'RB' - when he visited me at the University of Cape Town in the mid1990s, and I had the pleasure of taking him on a tour of our magnificent peninsula and to the lighthouse at Cape Point. He always mentioned this excursion whenever we met - which of course, was often following his election to the Vice-Presidency of the IGU. Our encounters became even more regular from 2018 when he took over from me as Secretary-General, and we worked together very closely on IGU business and more. 'RB' was a softly spoken and compassionate person who thought deeply about the subject that he loved so much. His contributions to the discipline - through his indefatigable endeavours in research publications, education and outreach - led to his being considered, quite rightly, as a true 'Giant of Geography in India' and beyond. He inspired generations of younger students to pursue our distinguished discipline and has served the global geographical community with great dignity. His countless followers, particularly in his home country, clearly adored him - as the innumerable 'likes' of his Facebook posts attest. 'RB' will be remembered as a placid, calm but tireless champion of 
global Geography and will be sorely missed by all who came into contact with this gentle soul. We all in the IGU, are devastated, and our hearts go out to his family, colleagues, students and close friends. May his soul rest in peace.

- Professor Michael E. Meadows, President IGU (2020-2024) University of Cape Town, South Africa. 27 August 2021. I worked with Professor R.B. Singh (19552021) closely for over two decades, first in IGU-LUCC (IGU Commission on Land Use/Cover Change) since the 1990s, then in a number of projects, meetings and publications in Japan and India related with land use/cover change, sustainability, disasters, environmental education, etc., while deepening our involvement in the IGU. In 2018 the IGU Executive Committee faced difficulty in finding a candidate for Secretary-General and Treasure for 2018-2022 because the workload of that post seemed hopelessly high. I, then President, was really saved when he said to me that he, then a Vice President, was prepared to take that difficult role if needed. It is my deepest regret that I failed to stop him from overworking for the IGU on top of the other also important duties when his health condition was not so good, then lost one of my best friends and unreplaceable comrade, Professor R.B. Singh on 22 July 2021. His kindness, high and wideranging academic expertise and zeal for education remain vivid in my mind forever. Let his soul rest in peace.

\section{- Professor Yukio Himiyama,} IGU President (2016-2020),

\& Emeritus Professor, Hokkaido University of Education, Japan, 25 August 2021. In 2006 we had the first larger international gathering to prepare the action plan for the IGU project "Culture and Civilizations for Human Development (CCHD)" at the Home of
Geography in Rome. At that occasion I met R.B. Singh for the first time. Together with (late) Anne Buttimer we were discussing the broadest possible inclusion of geographers from all parts of our planet. From then on, we met at many further events, especially in the context of the International Year of Global Understanding (IYGU). One of the most memorable is certainly the World Cultural Forum at Macao in 2016, where we represented geography, and where the idea was born that IGU shall became a member of the International Council for Philosophy and Human Sciences (CIPSH). In the following years I could experience R.B. Singh as an extremely engaged General Secretary of the IGU, mastering an incredible workload. When I was asking him on the last day of June 2021 to become a co-signatory of The Jena Declaration he responded as usual the same day. He apologized for being presently in hospital, but that he will be pleased to endorse the declaration after leaving the hospital in about four days.... With R.B. Singh we lost a gentle and devoted enthusiast who was aiming to integrate cultural diversity for joint action for the benefit of all.

- Professor Benno Werlen, Executive Director, International Year of Global Understanding \& Chair of the German National IGU Committee, UNESCO Chair on Global Understanding for Sustainability, Friedrich Schiller University Jena, Germany, 29 August 2021. I met R.B. Singh first time in Egypt in 1983, during a Conference of the IGU Commission on Resource Management in Drylands. Once again, the following year, during a similar Conference, this time in Delhi, and later at his invitation we visited his residence (the Aiyer Hostel, room no. 19, Banaras Hindu University). Many years passed, in 2006 under the aegis of IGU I had organized a 4-days Conference in Rome on "Cultures and 
Civilizations for Human Development", where he participated and had great discourses. Afterwards, quite every year we met again at international events. In 2008 I was voted for an IGU Vice President, and in the next election to renew the Executive Committee (2014), I suggested he present his Candidacy, and R.B. Singh had succeeded. In the following time, he organized IGU-India conferences every year; and also opened a series of geographical books, mostly with Springer Nature. The last time my wife and I met him was in Istanbul in 2019, when we observed speedy deterioration of his health. But in the following time, we were pleased to see that his activity was continuing as usual. Receiving the news of his sad demise on 22 July 2021 has been a great shock. We are glad that in the recent 34th IGC Istanbul (16-20 August 2021) the loss of Prof. R.B. Singh was felt by all the IGU community.

- Professor Giuliano Bellezza, Ex- Vice President IGU and Director-

Home of Geography, Rome, Italy. 22 August 2021.

Prof. RB Singh's untimely death on July 22, 2021 deeply saddened the entire Geography community. I had the opportunity to meet him after he was elected to IGU EC. I had the opportunity to meet him in different cities of the world, as well as in Istanbul, where I live, due to IGU meetings. He was also a wonderful host at the EC meeting in India. In all these works, I have always known him for his gentle and calm personality. I will always remember him as a great and important personality in the geography community. I will do what is necessary to carry out the IGU Secretary General, which he successfully carried out, with the same success. May God have mercy on him, may his soul rest in peace.
- Professor Dr. Barbaros Gönençgil,

IGU Secretary General

Head, Department of Geography Istanbul University, İstanbul-Turkey,

27 August 2021.

I had known Professor R.B. Singh or 'RB-ji' as I affectionately and respectfully called him, for almost thirty years, and it is hard to believe that he is no more. Professor Singh and I interacted in many IGU conferences in different parts of the world, representing India and South Africa, respectively. He also invited me regularly to participate in conferences in different parts of India. RB-ji had amazing powers of persuasion and sometimes gently coaxed me to attend, even when I had a difficult schedule. I have also contributed chapters to his edited book series. ... I believe that a hallmark of a good professor is how he treats his students. I have known many of RB-ji's students and followed some of their discussions on social media. I can safely say that RB-ji's students worshiped the very ground on which he walked. I have never heard RB-ji utter a harsh word against anyone, even when things sometimes did not go as planned in some conferences. In many respects he represented the epitome of simplicity and humility. In one of his last discussions with me, Professor Singh had discussed his IGU project with me which will have a huge global impact. He had mandated each of the 40 IGU Commissions to select a theme or sub-theme from one of the 30 SDGs for research. We must collectively ensure that this project continues. This will be a fitting memorial to Professor R.B. Singh.

\section{- Professor Brij Maharaj, Member SA-NC for IGU, Department of Geography, University of KwaZulu-Natal, Durban, South Africa. 28 August 2021.}

\section{The Vision that will Radiate}

From carrying the past to channelising the future, country to country, group to group, all he handled with his power of attachment, sacrifice, intimate discourses and honouring other's domain through solid networking. This way, he succeeded to learn and practice self-guidance to 
universal outlook, regardless of what others believe, love or hate him. However, his own enlightenment had always been making geography in serving the causes of emerging society in collaboration and support of his own students, mostly his own doctoral and project associates. In a way, one can say it was RBS's centric approach; nevertheless, it radiated the world and got honour and recognition to Indian Geography through his distinct personality. That is how he was called as "icon of Indian Geography in the emergence of the 21st century". His passage on the road of geography be symbolised as spoken by Buttimer (1993, p. 26), "arboreal representation of a career journey that reveal[s] latent and manifest[s] consistencies as they unfold throughout an entire career". However, his march in diverse directions denotes the evoking of geographic awareness in search of infinite, putting critical reflections, discovery and creative contractions at the margin. Of course, the "RBS Era" is closed on the 22nd of July 2021 by his sad demise. Nevertheless, his messages, visions, signposts, pathways and the frontier lines would always be here what he left for the coming young generations to follow. However, his gamut of publications would hopefully "elicit curiosity and insight about relationships between humanity and the physical earth in themes such as culture and landscape, sense of place, nature symbolism, or the history of ideas" what Buttimer (1993, p. 15) had once envisioned. Let his students and companions pave the path of unification at the place of fragmentation, human service instead of empiricist narration, and making bridges through geographic blocks of cement in furthering geography as intimate knowledge of deeper human understanding. R.B. Singh's contributions should be taken as an enlightened frame - road to unification in the Indian Knowledge System (IKS) - Bharatiya Jnana Paddhati (BJP), what Matthew \& Herbert (2004, p. 388) said "... that if greater emphasis is given to the unifying themes, Geography will make greater disciplinary and interdisciplinary contributions to knowledge and society, thereby fulfill its destiny amongst the constellation of disciplines". This was probably the message of R.B. Singh's life-long works.

Through his masses of research students, he followed the path that once Henry said it in his famous book, Die Empty (2013, p. 120):

If you have an idea, perform it.

If you know, give it out.

If you have a goal, achieve it.

Love, share and distribute, do not keep it inside.

Naturally, the use of geography has to be judged by its degree of transparency, originality, shared consciousness and its acceptance by the society in terms of its services, and making sense for dignity and peace. RBS had tried his best to do this noble task by collecting flowers from the various wilderness, technocratic landscapes, cognitive works and their associated attributes, and all these illustrated in his colossal mass of publications. Remember what Yi-Fu Tuan (2002, p. 52) once said, "[t]ransparency is the goal of intellect rather than of culture. As for the culture, one might almost say that its purpose is obfuscation. It provides people with a comfortable habitat that lies in the sun, but not too much."

Concerning the goodness and humbleness of RBS, I remember the saying of famous humanist American geographer, Yi-Fu Tuan (2008, p. 80), "[o]ne feels intuitively that goodness cannot be just one act, that it has to be an overall quality, almost innate, like a characteristic smile or tone of voice that is sustained over a life time". RBS had always maintained and kept alive that sense of goodness. RBS had started the run, spread the willpower and whatever integrity inside he had - all he transferred making himself "empty" at the end of his life, and now let his students and companions transform all those in service to the Global community; almost similar to what Swami Vivekananda (1863-1902) has envisioned and popularised the message for 'Global Understanding', based on the Vedic teaching: Utīshthata Jāgrata prāpya Varanni Bodhayata, that is, , "Arise, Awake and Stop not till the goal is Reached" (Kațha Upanishad, 1.3.14). Let us 
realise and reveal this and follow and strengthen the path as homage and tribute to (late) Professor R.B. Singh.

\section{References}

Buttimer, Anne (1983). The Practice of Geography. Longman.

Buttimer, Anne (1993). Geography \& the Human Spirit. The Johns Hopkins University Press.

Henry, Todd (2013). Die Empty: Unleash Your Best Work Every Day. Penguin Books Ltd (Portfolio Penguin).

Matthew, John A. and Herbert, David T., eds. (2004). Unifying Geography: Common Heritage, Shared Future. Routledge.

Roy, Shouraseni Sen (2021). Professor R.B. Singh (1955 2021). In Pandey, Bindhy Wasini and Anand, Subhash (eds.) Water Science and Sustainability (pp. 1-3). Sustainable Development Goals Series Springer Nature. DOI: 10.1007/978-3-030-57488-8_1

Sikka, Gaurav; Yenneti, Komalirani; Singh, R.B. and Tikunov, V.S., eds. (2021). Special issue on "Geospatiality and Sustainable Development Goals" of the Geography, Environment (the official journal of Russian Geographical Society. 14(1).

Singh, Rana P.B. (2013). The Hindu Family in Indian Society: Perspectives and Prospects. In: Angellio, Maria (ed.) The Family in the Cultures and Societies of Asia/ La famiglia nelle culture $e$ nelle società dell'Asia - Asiatica Ambrosiana, Saggi e ricerche di cultura religioni e società dell'Asia [AA presso la Biblioteca Ambrosiana Milano, Italy; Bulzoni Editore, Roma], nr. 5: pp. $19-48$.

Singh, Rana P.B. (1977). Clan Settlements in the Saran Plain: a Study in Cultural Geography, Varanasi: National Geographical Society of India, Banaras Hindu University, Res. Pub. 18.

Singh, Rana P.B. and Singh, R.B. (1981). Changing Frontiers of Indian Village Ecology: Case of a Bihari Village. Varanasi: National Geographical Society of India, Banaras Hindu University, Res. Pub. No. 27.
Tau, Byron (2012). Obama asks geography bee question. 05/24/2012 02:40 PM, https://www.politico.com/blogs/politico44/201 2/05/obama-asks-geography-bee-question124490

Tuan, Yi-Fu (2002). Dear Colleague: Common and Uncommon Observations. University of Minnesota Press.

Tuan, Yi-Fu (2008). Human Goodness.University of Wisconsin Press.

\section{Appendix 1: Publications}

\section{Published Books/Atlas Books/Atlas (16, cf. Table 4).}

1. Singh, Rana P.B. and Singh, R.B.: Changing Frontiers of Indian Village Ecology: Case of a Bihari Village, Majhanpura. Foreword: Prof. Walther Manshard, Secretary-General IGU. Varanasi: National Geographical Society of India, Banaras Hindu University, Res. Pub. No. 27; 88-pp.: 20-tables, 17-figures, 1981. [A model study of their own native village, under IGU WG on 'Transformation of Rural Habitat in Developing Countries'].

2. Singh, R.B.: Geography of Rural Development (a case study of Siwan district, Bihar). New Delhi, Inter India Publisher, 1986. [Revised doctoral dissertation of his own].

3. Singh, R.B.: Space Technology for Disaster Monitoring and Mitigation in India. INCEDE, Inst. of Industrial Science, University of Tokyo, 58-pp., 1994. (Based on a commissioned-project report).

4. Roy, Shouraseni Sen and Singh, R.B.: Climate Variability, Extreme Events and Agricultural Productivity in Mountain Regions. Oxford \& IBH Pub., New Delhi, 232-pp., 2002.

[Revised MPhil. dissertation of the first author].

5. Singh, R.B.: Practical Work in Geography, Part 1, Text Book for Class XI, NCERT, New Delhi, 65-pp., 2002. (Based on a commissioned-project report).

6. Singh, R.B.: Practical Work in Geography, Part 2, Text Book for Class XII, NCERT. New 
Delhi, 58-pp., 2003. (Based on a commissioned-project report).

7. Kumar, Bhuwan and Singh, R.B: Urban Development and Anthropogenic Climate Change-Experience in Indian Metropolitan Cities. Manak Pub., New Delhi, 216-pp., 2003. [Revised doctoral dissertation of the first author].

8. Singh, R.B.: Risk Assessment and Vulnerability Analysis. IGNOU PG Diploma in Disaster Management- MPA-003, New Delhi., 355-pp., 2005. (Based on a commissioned-project report).

9. Dey, B. and Singh, R.B.: Natural Hazards and Disaster Management. CBSE, Delhi, pages 45-pp., 2006.

www.cbse.nic.in/natural\%20hazards\%20\&\% 20disaster\%20management.pdf (an internet publication). (Based on a commissioned-project report).

10. Gritzner, Charles F., et al.: The World AtlasEarth Concise (jointly with several other Contributors including R.B. Singh), Millennium House Ltd., NSW, Australia, 576pp., 2008.

11. Singh, R.B. and Mal, Suraj: Environmental Change and Biodiversity. Rawat Publication, Jaipur, 2009. (Based on a commissionedproject report; partly based on doctoral dissertation by Suraj Mal).

12. Panwar, M. S., Sharma, S.K. and Singh, R.B.: Medicinal Plants and Sustainable Livelihood. R.K. Books, New Delhi, 342-pp., 2010. (Based on a commissioned-project report).

13. Singh, R.B.: Urban Sustainability, Health and Wellbeing and Disaster Risk Reduction. Prof. R.N. Dubey Foundation, Allahabad, 80-pp., 2015. [Thematic R.N. Dubey Memorial lecture].

14. Kumar, Dilip, Singh, R.B. and Kaur, Ranjeet: Spatial Information Technology for Sustainable Development Goals. AGES Series, Springer Nature Pte Ltd., Singapore, 2019. (Based on a commissioned-project report).

15. Grover, Aakriti and Singh, R.B.: Urban
Health and Wellbeing- Indian Case Studies. AGES Series, Springer Nature, Singapore, 2020. [Revised doctoral dissertation of the first author].

16. Singh, Swarnima and Singh R.B.: Simulating Climate Change and Livelihood Security: A Western Himalayan Experience, India. AGES Series, Springer Nature Pte Ltd., Singapore, 2021. [Revised doctoral dissertation of the first author].

Edited \& Co-edited Anthologies/Volumes (40: Se 1 - 40, cf. Table 5)

1. Singh, R.B.: Environmental Geography; Contribution to Indian Geography, vol. XI. New Delhi, Heritage Pub., 352+ xv pp. 1990.

2. Singh, R.B.: Environmental Monitoring Application of Remote Sensing and GIS. Hong Kong, Geocarto Int. Centre, 192-pp., 1991.

3. Singh, R.B.: Dynamics of Mountain Geosystems. New Delhi, Ashish Pub., 375pp.1991

4. Singh, R.B. and Haigh, Martin J.: Sustainable Reconstruction of Highland and Headwater Regions. New Delhi, Oxford \& IBH Pub. 681-pp. 1995.

5. Singh, R.B.: Global Environmental ChangePerspectives on Remote Sensing and GIS. New Delhi, Oxford \& IBH Pub., 321-pp. 1995.

6. Singh, R.B. and Majoral, R.: Development Issues in Marginal Regions. New Delhi, Oxford \& IBH Pub., 310-pp., 1996.

7. Singh, R.B. and Misra, S.: Environmental Law - Issues and Responses. New Delhi, Concept Pub. Co., 303-pp. 1996.

8. Singh, R.B.: Disasters, Environment and Development. New Delhi, Oxford \& IBH Pub., 600-pp., 1996.

9. Singh, R.B.: Research in Geography, Vol. II Disaster and Environment - Monitoring and Forecasting. New Delhi, APH Pub., 357-pp. 1996.

10. Singh, R.B.: Research in Geography, Vol I - 
Land Use Changes and Sustainable

Development. New Delhi, APH Pub., 335pp. 1996.

11. Becker, A. et al.: Predicting Global Change Impacts on Mountain Hydrology and Ecology: Integrated Catchment Hydrology/ Altitudinal Gradient Studies, (together with others including R.B. Singh), IGBP Commissioned Report 43. Royal Swedish Academy of Sciences, Stockholm, 61-pp., 1997.

12. Singh, R.B. and Murai, Shunji: Space Technology for Sustainable Development. Oxford \& IBH Publisher, New Delhi, 368-pp. 1998.

13. Singh, R.B.: Sustainable Development of Mountain Environment of India and Canada. New Delhi, Oxford \& IBH Pub., 345-pp.1998.

14. Singh, R.B.: Ecological Techniques and Approaches to Vulnerable Environment. New Delhi, Oxford \& IBH Pub., 255-pp., 1998.

15. Singh, R.B.: Disaster Management. Rawat Pub., Jaipur, 333-pp., 2000.

16. Singh, R.B., Fox, J. and Himiyama, Yukio: Land Use and Land Cover Change. Science Pub., Inc., Enfield (NH), USA and Oxford \& IBH Pub., New Delhi, 299-pp., 2001.

17. Singh, R.B.: Urban Sustainability in the Context of Global Change. Science Pub., Inc., Enfield (NH), USA and Oxford \& IBH Pub., New Delhi, 282-pp., 2001.

18. Singh, R.B.: Human Dimensions of Sustainable Development. Rawat Pub., Jaipur, 279-pp., 2002

19. Park, Namsik, Nakakita, E., Yoo, C. and Singh, R.B.: Advances of Geosciences: Vol. 4: Hydrological Sciences (HS), Ed., World Scientific Publishing Co., Singapore, 295-pp., 2006.

20. Singh, R.B.: Natural Hazards and Disaster Management. Rawat Pub., Jaipur, 352-pp., 2006.

21. Singh, R.B.: Sustainable Urban

Development. Concept Pub. Co., New Delhi, 431-pp., 2006

22. Mohammad, Noor, Singh, R.B. and Datta, Anindita: Spatial Information Technology for Natural Resources Management. Concept Pub. Co., New Delhi, 180-pp., 2007.

23. Jha, Mritunjay Mohan and Singh, R.B.: Land Use-Reflection on Spatial Informatics, Agriculture and Development. Concept Pub. Co., New Delhi, 318-pp., 2008

24. Singh, R.B.: Biogeography and Biodiversity. Rawat Publications, Jaipur, 340-pp., 2009.

25. Himiyama, Yukio, Kanda, F., Singh, R.B. and Hindson, J.: Global Environmental

Education. Rawat Publications, Jaipur, 246pp., 2010.

26. Singh, R.B.: Progress in Indian Geography- $A$ Country report, 2008-2012. The 32nd International Geographical Congress, Cologne, Germany (August 26-30, 2012). INSA- Indian National Science Academy, New Delhi, 198-pp., 2012.

27. Singh, R.B. and Hietala, R.: Livelihood Security in North-western Himalaya. Springer Nature, Singapore and Tokyo, 258pp., 2014.

28. Singh, Mehtab, Singh, R.B. and Hasan, M.I.: Climate Change and Biodiversity. Springer Nature, Singapore and Tokyo, 2014.

29. Singh, Mehtab, Singh, R.B. and Hasan, M.I.: Landscape Ecology and Water Management. Springer Nature, Singapore and Tokyo, 2014.

30. Singh, R.B.: Urban Development Challenges, Risk and Resilience in Asian Mega CitiesSustainable Urban Future of Emerging Asian Mega Region. Springer Nature, Singapore and Tokyo, 488-pp., 2015.

31. Singh, R.B.: Environmental Geography of South Asia, Contributions toward a future earth Initiative. Springer Nature, Singapore and Tokyo, Pages 351-pp., 2015

32. Singh, R.B., Schickhoff and Suraj Mal: Climate Change, Glacier Response, and Vegetation Dynamics in the Himalaya. AGES Series, Springer Nature Pte Ltd., Singapore, 
399-pp., 2016.

33. Singh, R.B.: Progress in Indian Geography (2012-2016), A Country Report. The 33rd International Geographical Congress, Beijing, China (August 21-25, 2016). INSAIndian National Science Academy, New Delhi: 214-pp., 2016.

34. Mal, Suraj, Singh, R.B. and Huggel, Christian: Climate Change, Extreme Events and Disaster Risk Reduction. AGES Series, Springer Nature Pte Ltd., Singapore, 309pp., 2018.

35. Singh, R.B., Wei, Dongying and Anand, Subhash: Global Geographical Heritage, Geoparks and Geotourism. AGES Series, Springer Nature Pte Ltd., Singapore, 2020.

36. Singh, R.B., Srinagesh, Bathula, and Anand, Subhash: Urban Health Risk and Resilience in Asian Cities. AGES Series, Springer Nature Pte Ltd., Singapore, 2020.

37. Singh, T.P., Singh, Dharmaveer, Singh, R.B.: Geo-intelligence for Sustainable Development. AGES Series, Springer Nature Pte Ltd., Singapore, 2021.

38. Mishra, Ram Kumar, Singh, R.B., Dubey, Anupama: Sustainable Climate Action and Water Management. AGES Series, Springer Nature Pte Ltd., Singapore, 2021.

39. Mishra, Mukunda, Singh, R.B.: COVID-19 Pandemic Trajectory in the Developing World: Exploring the Changing Environmental and Economic Milieus in India. AGES Series, Springer Nature Pte Ltd., Singapore, 2021.

40. Mishra, M., Singh, R.B., de Lucena, A.J., Chatterjee, S.: Regional Development Planning and Practice: Contemporary Issues in South Asia. AGES Series, Springer Nature Pte Ltd., Singapore, 2021.

\section{Research Papers in International Journal/Peer Reviewed (62: Se 1 to 64, cf. Table 6)}

1. Yadav, Ganesh; R.B. Singh, Subhash Anand, B.W. Pandey, Ashutosh Mohanty \& Sushree Sangita Dash: Ecological model analysis of respiratory health risk factors by ambient air pollution in Lucknow, the capital City of Uttar Pradesh, India. GeoJournal (E-ISSN: 1572-9893, P-ISSN: 0343-2521), vol. 86, 2021, https://doi.org/10.1007/s10708-02110490-7

2. Sikka, Gaurav; Komali Yenneti, R.B. Singh (2021). IGU-YECG Special Issue:

Geospatiality and Sustainable Development Goals. Geography, Environment, Sustainability (Russian Geographical Society, Moscow), vol.14, (1), pp. 6-8 https://DOI10.24057/2071-9388-2020-212.

3. Sahu, Netranand; Saini, A.; Behera, S.; Sayama, T.; Nayak, S.; Sahu, L.; Duan, W.; Avtar, R.; Yamada, M.; Singh, R.B.; Takara, K. (2020) Impact of Indo-Pacific Climate Variability on Rice Productivity in Bihar, India. Sustainability (MDPI Publs.) 12 (17), 7023 (Scopus, IF:3.251). https://doi.org/10.3390/su12177023

4. Yadav, Ganesh, R.B. Singh, Subhash Anand, and B.W. Pandey: National Capital Region (NCR) acts as a crucial engine of the Indian economy. Journal of Urban and Regional Studies on Contemporary India [The Center for Contemporary India Studies, Hiroshima], 7 (1), 2020, pp. 11-23.

5. Rahaman S., Kumar, P., Chen, R., Meadows, M.E. and Singh, R.B. (2020) Remote Sensing Assessment of the Impact of Land Use and Land Cover Change on the Environment of Barddhaman District, West Bengal, India. Frontiers in Environmental Science, 8: 127. https://doi.org./ 10.3389/fenvs.2020.00127

6. Abhishek Banerjee, Ruishan Chen, Michael E. Meadows, R.B. Singh, Suraj Mal and Dhritiraj Sengupta (2020) An Analysis of Long-Term Rainfall Trends and Variability in the Uttarakhand Himalaya Using Google Earth Engine. Remote Sensing (MDPI Publs.), 12, 709; https://doi.org./10.3390/rs12040709. IF 4.1

7. Mal Suraj, Mehta, Manish, Singh, R.B., Schickhoff, Udo, Bisht, M.P.S. (2019) Recession and morphological changes of the debris-covered Milam Glacier in Gori Ganga valley, Central Himalaya, India, derived from 
satellite data. Frontiers in Environmental Science, section Interdisciplinary Climate Studies, ID: 380587.

8. Panda, Arpita, Sahu, N., Behera, S., Sayama, T., Sahu, L., Ram Avtar, Singh, R.B, and Yamada, M. (2019) Impact of Climatic Variability on Crop Yield in Kalahandi, Bolangir and Koraput Districts of Odisha, India. Climate, 7, 126, https://doi.org./10.3390/cli7110126, 1-12.

9. Kumar, Manish, Singh, R.B., Pravesh, Ram, Kumar, Pankaj, Tripathi, Dinesh Kumar and Sahu, Netranand (2018) Urban Growth Dynamics and Modeling using Remote Sensing Data and Multivariate Statistical Techniques. Current Science, vol. 114, NO. 2080 10, 25 May, 2080-91 (Impact factor:0.756, Scopus indexed)

10. Janmaijaya, Mansi, Singh, R.B. and Dhaka, S.K. (2018), Detection of temperature variability and trends in the lower troposphere over Delhi: A study of joint influence of ENSO and Land use/ Land cover during 1980-2015. Singapore Jl. of Tropical Geography, https://doi.org./10.1111/sjtg.12251 (Impact factor:1.30, Scopus indexed).

11. Khetwani, Sagar and Singh, R.B. (2018) Assessment of Hydrological Drought in Marathwada Region: A Spatio-Temporal Analysis. Journal of Geography, Environment and Earth Science International, 17 (1), pp.110.

12. Kumar, Pankaj, Husain Arif, Singh R.B., Kumar Manish: Impact of land cover change on land surface temperature: A case study of Spiti Valley. Journal of Mountain Science [Institute of Mountain Hazards and Environment, CAS and Springer-Verlag GmbH Germany, part of Springer Nature], (2018) 15 (8), pp. 1658-1670, 2018. https://doi.org/10.1007/s11629-018-49029.

13. Khetwani, Sagar and Singh, R.B. (2018) Groundwater Dynamics in Marathwada Region: Spatio-Temporal Analysis for Sustainable Groundwater Resource
Management. International Journal of Conservation Science, Vol. 9, Issue 3, JulySeptember, pp.537-48.

14. Haque, Senaul and Singh, R.B. (2017) Air pollution and human health in Kolkata, India: A case study. Climate, 5, 77; https://doi.org./10.3390/cli5040077, 2-16. (Scopus indexed).

15. Nigam, G. K., Sahu, R. K., Sinha, M. K., Deng, X., Singh, R.B and Kumar, P. (2017) Field assessment of surface runoff, sediment yield and soil erosion in opencast mines in Chirimiri area, Chhattisgarh, India. Journal of Physics and Chemistry of Earth. https://doi.org./ 10.1016/j.pce.2017.07.001 (Impact factor:1.426, Scopus indexed).

16. Sahu, Netranand, Robertson A., Boer R., Behera S., DeWitt D.G., Kaoru T., Kumar M., Singh R.B. (2016): Probabilistic Seasonal Streamflow Forecasts of the Citarum River, Indonesia, Based on General Circulation Models. Journal of Stochastic Environmental Research and Risk Assessment, 2016, https://doi.org./10.1007/s00477-016-12974, (Impact factor: 2.8, Citation: 10, Scopus indexed).

17. Goswami, Nitu and Singh, R.B. (2017). Health Seeking Behaviour in Stress Management: A Case Study of French Tourist Community in Kangra, Himachal Pradesh. HSOA Jl. of Community Medicine and Public Health Care, 4: 024.

18. Grover, A. and Singh, R.B.: Monitoring spatial patterns of land surface temperature and urban heat island for sustainable megacity: A case study of Mumbai, India using Landsat TM data. Environment and Urbanization Asia (ISSN: 0975-4253), 7(1): 117, 2016.

19. Singh, R.B., Janmaijaya, Dhaka, S.K. and Kumar, V. (2015). Study on the association of greenhouse gas (CO2) with monsoon rainfall using AIRS and TRMM satellite observations. Physics and Chemistry of Earth, 89-90 (2015), https://doi.org./10.1016/j.pce.2015.04.004, 65-72. (Impact factor:1.968, Citation: 6, 
Scopus indexed)

20. O'Shea, P.M., Roy, S.S., \& Singh, R.B. (2015). Diurnal variations in the spatial patterns of air pollution across Delhi. Theoretical and Applied Climatology, 1-12. https://doi.org./: 10.1007/s00704-015-1441-y (Impact factor: 2.72, Citation: 2 )

21. Singh, R.B. and Kumar, Ajay (2015). Climate variability and water resource scarcity in drylands of Rajasthan, India.

Geoenvironmental Disasters, 2:7, https://doi.org./ 10.1186/s40677-015-00185, 1-10. (Citation: 7 )

22. Singh, R.B. and Grover, Aakriti (2015). Analysis of urban heat island (UHI) in relation to Normalized Difference Vegetation Index (NDVI): A comparative study of Delhi and Mumbai. Environments, 2, 125-138;

https://doi.org./10.3390/environments 2020125.

23. Singh, R.B., Haque, Senaul and Grover, Aakriti (2015). Drinking water, Sanitation and Health in Kolkata Metropolitan City: Contribution towards Urban Sustainability, Geography, Environment, Sustainability, No. 4 (V.08).

24. Singh, R.B., Grover, Aakriti and Zhan, Jinyan (2014). Inter-Seasonal Variations of Surface Temperature in the Urbanized Environment of Delhi Using Landsat Thermal Data.

Energies, 7, https://doi.org./10.33901en7031811, (Impact factor:2.6, Citation: 45, Scopus indexed).

25. Singh, R.B. and Grover, Aakriti (2014). Remote sensing of urban microclimate with special reference to urban heat island using Landsat thermal data. Geographica Polonica, 87 (4), 555-568, https://doi.org./10.7163/GPol.2014.38

26. Singh, R.B. (2014). Emerging frontiers, challenges and changing professional avenues for geographers in the contemporary world. Geographica Polonica, 87 (2), 203-212,
https://doi.org./10.7163/GPol.2014.12

27. Singh, R.B. and Shi, C. (2014). Advances in Observation and Estimation of Land Use Impact on Climate Changes: Improved Data, Upgraded Models and Case Studies.

Advances in Meteorology DX. https://doi.org./10.1155/2014/748169. (Impact factor:1.277, Citation: 7) Scopus indexed).

28. Singh, R.B. and Suraj Mal: Trends and Variability of Monsoon and other Rainfall Seasons in Western Himalaya. Atmospheric Science Letters, https://doi.org./10.1002/asl2.494, 2014. (Impact factor 1.796, Citation: 38 )

29. Sahu, N., Singh, R.B., Kumar, Pankaj, Da Silva, R.V. and Behera, S.K: La Nina Impacts on Austral Summer Extremely HighStreamflow Events in the Paranaiba River in Brazil. Advances in Meteorology DX. https://doi.org./10.1155/2013/461693, 2013. (Impact factor:1.277, Citation: 2 , Scopus indexed).

30. Sahu, N., Behera, S.K., Ratnam, J.V., Da Silva, R.V., Parhi, P., Duan, W., Takara, K., Singh, R.B. and Yamagata, T.: El Nino Modoki Connection to Extremely-Low Streamflow of the Paranaiba River of Brazil. Climate Dynamics, DOI 10.1007/s00382-013-2006-3, 2014. (Impact factor: 4.04, Citation: 10 , Scopus indexed)

31. Ma, Maohua, Haapanen, Toni, Singh, R.B. and Hietala, R.: Integrating Ecological Restoration into CDM Forestry Projects. Environmental Science and Policy, vol. 30, 2013. (Impact factor:4.81, Citation:14, Scopus indexed).

32. Mal, Suraj and Singh, R.B.: Differential Recession of Glaciers in Nanda Devi Biosphere Reserve, India. IAHS Red Book 360, pp. 71-76, 2013.

33. Singh, R.B., Gahlot, S. and Singh, Anju: Ecohydrological Perspectives of Declining Water Sources and Quality in Traditional Water Bodies in Delhi. IAHS Red Book 361: pp. 361-68, 2013 (Citation: 5). 
34. Singh, R.B. and Anand, Subhash: Geodiversity, Geographical Heritage and Geoparks in India. International Jl. of Geoheritage,1 (1), pp. 10-26, 2013, Citation:7.

35. Anand, Anupam, Chandan, Pankaj and Singh, R.B.: Homestays at Korzok: Supplementing Rural Livelihoods and Supporting Green Tourism in the Indian Himalayas. Mountain Research and Development, 32(2), 2012: pp.126-36. (Impact factor:1.149, Citation: 26, Scopus indexed)

36. Ma, Maoha, Singh, R.B. and Hietala, H.: Human driving forces for ecosystem services in the Himalayan region, Environmental Economics, 3 (1), 2012: pp. 53-57, Citation: 9).

37. Singh, R.B. and Kumar, Dilip: Remote sensing and GIS for land use/cover mapping and integrated land management: case from the middle Ganga plain. Front. Earth Sci., 6(2), 2012. (Impact factor:1.051, Citation: 8, Scopus indexed).

38. Sahu, Netranand, Yamashiki, Y, Avatar, Ram, Singh, R.B. and Takara, Kaoru: Impact of ENSO on the Paranaiba Catchment, Brazil. Annuals of Disaster Preventive Res. Inst., Kyoto University (Online Jl.), No.55B, 2012.

39. Singh, R.B. and Kumar, Ajay: Climate Variability in Dry Regions of India: Case Study of Rajasthan. Scientific Annals of Alexandro IOAN CUZA University of IASI, Vol. LVIII, pp.59-76, 2012.

40. Singh, R.B. and Singh, S.: Rapid Urbanization and Induced Flood Risk in Noida, India. Asian Geographer, Vol. 28, Issue 2, 2011, pp. 147-69, (Citation: 13)

41. Sen Roy, Shouraseni, Singh, R.B. and Kumar, Manoj: An Analysis of Local Spatial Temperature Patterns in the Delhi Metropolitan Area. Physical Geography, vol. 32, pp. 114-38, 2011, (Citation: 19).

42. Sahu, Netranand, Yamashiki, Y, Takara, Kaoru and Singh, R.B.: An Observation on the Relationship between Climate Variability
Modes and River Discharges of the Citarum Basin, Indonesia. Annuals of Disaster Preventive Res. Inst., Kyoto University (online JI.), No. 54B, pp. 49-55, 2011

43. Singh, R.B. and Kumar, Subodh: Mountain Risks in Downstream Water Resource Management in Upper Bhagirathi Basin. In: Indian Himalayas. IAHS Red Book Pub. 347, pp. 49-54, 2011.

44. Singh, R.B. and Chandana, Vaneeta: Spatial Analysis of the Yamuna Water Quality in Pre and Post Monson Periods. IAHS Red Book Pub. 348, pp. 8-13, 2011.

45. Singh, R.B., Mal, Suraj and Kala, C.P.: Community Response to Mountain TourismA Case in Bhyundar Valley, Indian Himalaya. Journal of Mountain Science, Vol. 6, No.4, December, pp.394-404, 2009. (Impact factor:1.151, Citation:19, Scopus indexed).

46. Singh, R.B.: Integrated Water Resources Management in the Vulnerable Indian Environment. IAHS Red Book 330, pp. 18793, 2009.

47. Goel, A. and Singh, R.B.: Sustainable Forestry in Mega-cities of India for Mitigating Carbon Sequestration: Case Study of Delhi. Advances in Earth Science, Vol. 21, No. 2, Feb., pp.144-150, 2006.

48. Goel, A. and Singh, R.B.: Climate Variability and Drought in Rajasthan. In: Advances of Geosciences: Vol. 4: Hydrological Sciences (HS), Ed., World Scientific Publishing Co., Singapore, pp. 57-68, 2006.

49. Singh, R.B. and Mishra, D.K.: Green Tourism in Mountain Regions-reducing Vulnerability and promoting People and place Centric Development in the Himalayas. Journal of Mountain Science, Vol. 1, No. 1, pp. 57-64, 2004. (Impact factor:1.151, Citation: 26, Scopus indexed).

50. Singh, R.B.: Assessment of Wastewater Generation, Management Pattern and its Re-Use Potential in Urban India. IAHS Red Book 285, pp. 19-22, 2004.

51. Gardner, James, Sinclair, John, Berkes, Fikret and Singh, R.B.: Accelerated Tourism 
Development and its Impacts in KulluManali, H.P., India. Tourism Recreation Research, Vol. 27 (3), pp. 9-20, 2002 (Citation: 26).

52. Singh, R.B.: Sustainable Management of Water Resources in an Agriculturally Developed Region of the Indo-Gangetic Ecosystem, India, Pub. In: FRIEND 2002Regional Hydrology: Bridging the Gap Between Research and Practice. IAHS Red Book 274, pp. 315-21, 2002.

53. Singh, R.B.: Impact of Land-use change on groundwater in the Punjab-Haryana Plains, India, Pub. In: Impact of Human Activity on Groundwater Dynamics. IAHS Red Book 269, pp. 117-122, 2001.

54. Singh, R.B.: Sustainable Regional Water Management in the Yamuna River Basin: Case Study of Delhi Region, Pub. In: Regional Management of Water Resources. IAHS Red Book 268, pp. 25-32, 2001.

55. Singh, R.B.: Environmental Consequences of Agricultural Development: A Case study from the Green Revolution State of Haryana, India. Agriculture, Ecosystem and Environment, 1637, 2000, pp. 1-7, (Impact factor: 3.541, Citation: 333).

56. Singh, R.B.: Land Use and Cover Change and Comprehensive Food Security in the IndoGangetic Plains: Challenges and Responses. Journal of Geography Education, Vol. 43, pp. 27-31, 2000.

57. Singh, R.B.: Urban Impact on Groundwater Quality in the Delhi Region. IAHS Red Book 259, pp. 227-234, 1999, (Citation: 15).

58. Duffield, C., Gardner, J.S., Berkes, F. and Singh, R.B.: Local Knowledge in the Assessment of Resource Sustainability: Case Studies in Himachal Pradesh, India and British Columbia. Canada. Mountain Research and Development, vol.18, No.1, 1998, pp. 35-49. (Impact factor:1.149, Citation:51, Scopus indexed)

59. Singh, R.B.: Land Use/Cover Changes, Extreme Events and Ecohydrological Responses in the Himalayan Region.
Hydrological Processes, 12, 1998. (Impact factor:3.189, Citation: 55, Scopus indexed).

60. Singh, R.B. and Verma, R.P.: Monitoring Hydrological Parameters and Sustainable Water Resource Development in the Mahanadi River Basin. Acta Hydrotechnica, 15/19, 1997, pp.159-162.

61. Singh, R.B.: Water Resources Monitoring for Environmental Sustainability under increasing uncertainty in the Himalayan Region. In: Sustainability of Water Resources Under Increasing Uncertainty, IAHS Red Book 240, 1997, pp. 479-485.

62. Singh, R.B. and Pandey, B.W.: Environmental Monitoring of Particulate Matter and Pollution in Major Rivers of India. In: Particulate Matter in Rivers and Estuaries, Hamburg: Max Planck Inst. pp. 246-251, 1994, published in Advances in Limnology, Vol. 47, 1996. pp.557-561.

63. Singh, R.B.: Spatial Distribution of rural Settlement System: Micro-Level Indian Case Study. Asian Geographer, Vol. 1, No. 2, 1982, pp. 51-56.

64. Singh, Rana P.B. and Singh, R.B.: Ecological Perspectives of Rural Development in North Indian Plain: A Case of Siwan District. Geographica (Singapore), vol. 13, 1979, pp. 49-57.

\section{Research Papers in Indian Journals/Books (62: Se 65 to 126, cf. Table 7):}

65. Prasad, Sant, R.B. Singh, and Bindhy Wasini Pandey: Spatio-Temporal Analysis of Land Use and Land Cover in Delhi-NCR Using Satellite Data. Journal of Global Resources, 7 (2), July 2021, pp. 23-31.

66. Mal, Suraj, Atul Kumar, Rakesh Bhambri, Udo Schickhoff, and R.B. Singh: Inventory and Spatial Distribution of Glacial Lakes in Arunachal Pradesh, Eastern Himalaya, India. Journal of the Geological Society of India, 96 (6), December 2020, pp. 609-615

67. Prasad, Sant, R.B. Singh, and Bindhy Wasini Pandey: Spatio-Temporal Analysis of Land Use and Land Cover in Delhi-NCR Using Satellite Data. Journal of Global Resources, 7 
(2), July 2021, pp. 23-31.

68. Khetwani, Sagar and Singh, R.B. (2019) Comparative Impact Analysis of drought in Marathwada Region, India. Ecology, Environment and Conservation, 25 (2), pp.721-28.

69. Paarcha, Aruna and Singh, R.B. (2019) Land use and land Cover dynamics in Dehradun City and Surroundings. Review of Research, vol. 8, issue 5, February, pp.1-13.

70. Nirbhav and Singh, R.B. (2019) landslide risk Mitigation Methods Along the Transport Corridor: A Case Study of KulluRohtang Pass. International Journal of Social Science and Economic Research, vol. 4, Issue 1, January, pp. 107-125.

71. Banerjee, Abhishek, Singh, R. B. and Mal, Suraj (2018) Assessment of landslide Hazard in Mountainous Terrain: A Case Study of Bhilangana River Basin. Hill Geographer, vol. 34, No.2, pp. 51-61.

72. Singh, R.B. (2017) Ensuring clean water accessibility and mitigating water induced disasters-Contributing towards Sustainable Development Goals. Productivity, 57 (4), Jan-March, pp. 323-331.

73. Singh, R.B. and Haque, Senaul (2016) Urban ambient air quality and respiratory health in Kolkata: A dispensary level analysis. Journal of Urban and Regional Studies, 2 (1), February, 7-21.

74. Nitu and Singh, R.B. (2016) Dynamics of hill agriculture in emergent rural economy of Kangra district, Himachal Pradesh. Journal of Soil and Water Conservation, 15 (4): 337344, October-December, https://doi.org./10.5958/24557145.2016.00019.9.

75. Singh, R.B. (2016). Climate, Disaster and Livelihood Security. Contribution towards Sendai Framework of Disaster Risk Reduction, NAM Today, vol. LV, No. 02, 2-4.

76. Singh, R.B. (2016). Disaster Risk ReductionAgenda before Academics, policy Makers. World Focus, No. 437, 5-11.
77. Singh, R.B. and Kumar, Ajay (2015). Understanding climate change-induced disasters for sustainable future earth, case studies of Rajasthan and Uttarakhand Himalaya. World Focus, October 2015, 2333.

78. Singh, R.B., Pandey, B.W. \& Prasad, Abhay Shankar (2014) Adaptation strategies for flood risk mitigation in lower Brahmaputra River basin, Assam through integrated river basin management. Transactions of the Institute of Indian Geographers, 36 (2), 159-170.

79. Singh, R.B., Pandey, B.W. \& Prasad, Abhay Shankar (2014). Extent and Magnitude of Flood due to Soil Erosion in Lower Brahmaputra River Basin Assam. Annals, National Association of Geographers of India (NAGI), 34 (2), 162-179.

80. Thakur, Swati and Singh, R.B. (2014). Climate variability in the foothills of Indian Central Himalayan Region. Regional Symbiosis, vol. 22, 51-64.

81. Singh, R.B., Pandey, B.W. \& Prasad, Abhay Shankar (2014). Living With Flood and Sustainable Livelihood Development in Lower Brahmaputra River Basin Assam. Golden Research Thoughts, 3 (10), 1-10.

82. Singh, R.B. \& Janmaijaya, M. (2014). Anthropogenic activities impacting temperature variations over Delhi. International Journal of Applied Sciences and Humanities, 14, 54-60.

83. Singh, R.B. \& Janmaijaya, M. (2014). Monsoon: mechanism, variability and emerging issues. International Journal of Applied Sciences and Humanities, 3, pp. 8892.

84. Singh, R.B. \& Kumar, A. (2013). Land use land cover change in peripheral National Capital Region: A case study of Alwar district, Rajasthan. Journal of Water and Land use Management, 13 (2) 13-24 (ISSN 0973-9300)

85. Singh, R.B. \& Kumar, A. (2013). Impact of changing monsoon pattern on dryland 
agriculture in India: A case of Nagaur district, Rajasthan. Journal of Water and Land use management, 13 (1),1-14.

86. Mehtab Singh and R.B. Singh (2013): Change in Land Use and Land Cover through Watershed Development Programme: A Case of Nakti Nadi Sub Watershed in Haryana Shiwaliks. The Horizon- A Jl. of social Science, Vol.4 (1), pp.11-19.

87. Singh, R.B. and Nath, Rituparna (2012): Remote Sensing, GIS and Micrometeorology for Monitoring and Predicting Urban Heat Islands in Kolkata Mega City. Annals of NAGI, vol. 32 (1), pp.17-39.

88. Gupta, Rupesh and Singh, R.B.: Population Growth and Land Use Change Analysis of Jaipur City using Remote Sensing and GIS Techniques. Hill Geographer, 27 (1\&2), pp.75-84, 2011.

89. Singh, R.B. and Kumar, Rajesh: Assessment of Climate Variability in the Dry Regions of Haryana. Journal of Landscape Systems and Ecological Studies, vol. 34 (2), pp. 23-32, 2011.

90. Singh, R.B. and Gurjar, A.K.: Climate change Vulnerability of Agriculture in Arid Region of Rajasthan, India. Annals, National Association of Geographers of India (NAGI), 30 (1), pp. 22-38, 2011.

91. Singh, R.B. and Kumar, Subodh: Hazard Risk Assessment and Disaster Management Strategies in Mountains, World Focus, Vol. 32, No.3, pp.143-52, 2011.

92. Singh, R.B.: Geospatial Information Technology for Governance and Education in India: Focus on Disaster Management and Agriculture Development. Charmanvati: Research Jl. of Geography, vol. 10, pp. 1-10, 2010.

93. Sati, V.P. and Singh, R.B.: Migration and Agrarian Changes in Mountain Regions: A Case Study of the Pindar Basin of Uttarakhand Himalaya, India. Annals, National Association of Geographers of
India (NAGI), vol. 29, No. 1, June, pp. 20-33, 2009.

94. Singh, R.B.: Remote Sensing and Geographical Information System, Pub. In: Geography in India-Selected Themes, Ed. L.S. Bhat, Pearson, Delhi, pp.203-257, 2009. Also see Remote Sensing Research in India: Trends and Prospects, in Transactions of the Institute of Indian Geographers, vol. 15, No. 1, 1993, pp. 71-83 also published in: Third World Impact, June-Aug. 1993.

95. Singh, R.B.: Mitigating Natural Disasters for Achieving Inclusive Development and Human Security in India. Journal of Social Science, vol. 10, No.2, July-December, pp. 258-572, 2008.

96. Singh, R.B. and Chauhan, G.S.: Hydrology for sustaining Planet Earth and Biodiversity: Indian Experience. Indian National Geographer, vol. 23, No. 1\&2, pp. 1-6, 2008.

97. Singh, R.B. and Anand, Subhash: Current Status of Municipal Solid Waste Management Practices in Delhi. Annals, National Association of Geographers of India (NAGI), vol. 28, No. 1, June, pp. 36-50. 2008.

98. Singh, Mehtab, Kumar, Suresh, Singh, R.B. and Prasad, J.: Estimation of Soil Erosion by Using RUSLE and GIS for a Himalayan SubWatershed in India. Annals, National Association of Geographers of India (NAGI), vol. 27, No. 2, December, pp. 1-11, 2007.

99. Singh, R.B.: Hydro-informatics for Integrated Watershed ManagementCombining Science and Community Participation. Indian National Geographer, vol. 21, No. 1 \& 2, pp. 59-66, 2006.

100. Singh, R.B. and Anand, Anupam: Biodiversity in the High-Altitude Lakes of Ladakh: Threats and Opportunities. Annals, National Association of Geographers of India (NAGI), Vol. 26, No.2, December, pp. 10-17, 2006.

101. Singh, R.B.: Geographical Mosaics of Culture, Environment and Human 
Development. Annals, National Association of Geographers of India (NAGI), vol. 25, No.2, December, pp. 20-32, 2005.

102. Singh, R.B.: Prediction in Ungauged Basins (PUB): Hydrological Challenges for India, Annals, National Association of Geographers of India (NAGI), vol. 22, No.1, June 2002, pp. 89-98. Also Pub. In: PUB as Disaster Mitigation Tool in the Himalayan River Basin, Proceeding of the World Congress on Natural Disaster Mitigation, vol. 2, The Institution of Engineers (India), New Delhi, pp.256-64, 2004.

103. Singh, R.B.: Impact of Climate Change on Water Resources Sustainability in the Himalayan-Gangetic Region. Annals, National Association of Geographers of India (NAGI), Vol XXIV, No 1, pp.32-39, 2004, Also in Water Resources Sustainability in the Context of Increasing Disasters in the Himalaya-Gangetic Region; in: Proceedings of the 2nd Asia Pacific Association of Hydrology and Water Resources Conference, Vol. 11, AOGS, Singapore, pp. 566-74., 2004.

104. Singh, R.B., Kumar, B. and Singh, Anju: Mapping Environmental Stress in the Context of Land Use Changes and urban Sprawl in Delhi Metropolitan Region. The Geographer, vol. 49, Number 2, July, pp. 44-60, 2002

105. Singh, R.B.: Management of Water Related Disasters in the Context of the Himalayan Mountain Region of India. Annals, National Association of Geographers of India (NAGI), Vol. 21, No. 2, December 2001, pp. 41-46.

106. Singh, R.B. and Kumar, B.: Levels of Atmospheric Quality in Mumbai, Calcutta and Delhi. The Indian Geographical Journal, vol. 74, No.2, December, pp. 112-25, 1999.

107. Singh, R.B. and Kumar, Umesh: Rainfall Variability and its Relation with climate and Ecosystem: A Case of Western India. Indian $\mathrm{Jl}$. of Landscape System and Ecological Studies, vol. 22, No.1, June, pp. 29-35, 1999.
108. Singh, R.B. and Kumar, B.: Prediction and Detection of Anthropogenic Climate Change: Case of Delhi. Transactions of the Institute of Indian Geographers, Vol. 21, No.1, Jan., pp. 61-75.1999.

109. Singh, R.B.: Human Dimensions of Environmental Change: Geographical Perspective. Bhartiya Samajik Chintan, vol. 22, Nos. 1-4, Jan.-Dec., pp.55-60, 1999.

110. Singh, R.B.: Remote Sensing and GIS as Decision Support System in the Himalaya. Annals, National Association of Geographers of India (NAGI), vol. 12, No. 1 \& 2, 1992, pp.103-11. Also pub. In Application of GIS Technology for Environmental Monitoring and Forecasting in India. In: Research Methodology in Geography, Eds. H.N. Mishra and V.P. Singh. Jaipur \& New Delhi: Rawat Publications, 1998, pp.255-71.

111. Singh, R.B.: Urbanization, Environmental Crisis and Urban Planning in India. The Geographer, vol. 44, No. 2., July 1997, pp. 5-21.

112. Singh, R.B. and Chauhan, Gambhir S.: Environmental Regeneration of Wasteland through Agroforestry in Rajasthan. The Geographer, vol. 44, No. 1, Jan. 1997. 79.

113. Singh, R.B.: Hydrological Monitoring for Integrated Watershed Management in India. Indian Cartographer, Vol. 17, pp. 260-64, 1997.

114. Singh, R.B.: Forest and Forestry in India: Spatial Nature, Uses \& Issues of Sustainability, National Geographical Journal of India, vol. 41, March 1995, pp. 55-67.

115. Singh, R.B. and Kumar, Bhuwan: Spatial Variability of Anthropogenic Influences on Atmospheric Chemistry in Indian MegaCities. Geographical Review of India, vol. 55, No.1, 1993, pp. 22-33.

116. Singh, R.B. and Pandey, B.W.: Environmental and Human Response to Hydro-geomorphology: Micro-Level Experience of Ganga Basin. Journal of 
Scientific Research (B.H.U., Varanasi), vol. 43, (1\&2) 1993. pp. 153- 167.

117. Singh, R.B.: Geographical Monitoring of Himalaya Highland - Lowland Interactive Systems, National Geographical Journal of India, vol. 37 pt. 3, 1991, 272- 281; also published in: Environment-Yesterday, Today and Tomorrow, eds. H.P. Bhatt and S. Bhatt. Galgotia Pub., New Delhi, 1992, pp. 238-57.

118. Singh, R.B.: Application of Digital Image Processing and GIS Technology for Land Use Mapping and Monitoring the Land Degradation Hazards in U.P. Himalaya. Indian Cartographer, Vol. IX-I, 1989, pp. 432-42; also published in: Environmental Monitoring, Ed. R.B. Singh. Geocarto Int. Centre, Hong Kong, 169-78, 1991.

119. Singh, R.B.: The role of Education in Rural Development: Spatial and Structural Strategy in Rural India. The Indonesian Jl. of Geography, Vol. 10, No. 39, 1980, pp. 45-53; also published in: Human Resource Development, Ed. A. Kumar, Anmol Pub., New Delhi, 1991

120. Singh, R.B. and Khan, A.R.: Determinants of Energy Use - A study of Rural Delhi. Indian National Geographer, Vol. 2 (1\& 2), 1987, pp. 69-78.

121. Kayastha, S.L. and Singh, R.B.: Energy Potentialities and Related Rural Programmes in India: An Assessment of Emerging Trends. National Geographical Journal of India, vol. 31, pt. 2, 1985, pp. 147-50.

122. Ansari, Syed Hasan and Singh, R.B.: MicroLevel Development Planning of Mohamadpur Gram Panchayat. The Jl. of Scientific Research (B.H.U. Varanasi), vol. 33 (2), 1983, pp.145-56.

123. Singh, R.B.: The role of Rural Industralization Towards Eradication of Rural Poverty: Case Study of Siwan District. Rural System, vol. I Part 3, Varanasi, 1983, pp. 225-36; also in: Manpower Planning in India, ed. A. Kumar, Criteria Pub., New
Delhi, 1989, pp.141-158.

124. Singh, R.B.: Demographic Structure and Topology of Population Resource, A Case Study of Siwan District (Bihar). Indian Geographical Studies, Res. Bull. 16, 1981, Patna, pp. 33-40.

125. Kayastha, S.L. and Singh, R.B.: Regional Development through Social Planning: A Micro - level Study from India. Indian Jl. of Regional Science, Vol. 13, No. 1, 1981, pp. 28-45.

126. Kayastha, S.L. and Singh, R.B.: Emerging Dynamics of Integrated Rural development. National Geographical Journal of India, vol. 26, pt. 3-4, pp. 28-38, 1980.

\section{Research Papers in International Books and Proceedings (58, Se 127-184, cf. Table 8):}

127. Singh, R.B. and Ajay Kumar: Cultural Tourism based Regional Development in Rajasthan, India. In: Ravi S. Singh, Bharat Dahiya, Arun K. Singh, and Padma C. Poudel, (Eds.), Practising Cultural Geographies: Essays in Honour of Rana P.B. Singh. Advances in 21st Century Human Settlements series (ISSN: 2198-2546). Springer Nature Pte Ltd., Singapore, ca 201218 (chapter 18), 2022.

128. Mishra, Mukunda and R.B. Singh: Regional science, Regional Planning, and the Global south. In: Singh, R.B., Chatterjee, S., Mishra, M., De Lucena, A.J. (eds.) Practices in Regional Science and Sustainable Regional Development: Experiences from the Global South. Springer Nature Pte Ltd., Singapore, pp. 3-21, 2021.

129. Singh, R. B. and Grover, Aakriti: Air pollution and Human Health: The Case Study of Delhi Megacity, India. In: Global Change and Future Earth, The Geoscience Perspective, Eds. Tom Beer, Jianping Li and Keith Alverson. Cambridge University Press: pp. 223-36, 2018.

130. Singh, R. B., Swarnima Singh, and Shouraseni Sen Roy: Assessing Climate Change Signals in Western Himalayan District Using PRECIS Data Model. In: Singh, 
R.B., Schickhoff, Udo, Mal, Suraj (Eds.) Climate Change, Glacier Response, and Vegetation Dynamics in the Himalaya. Contributions Toward Future Earth Initiatives. Springer International Publishing Switzerland, Cham: pp. 103-115, 2016.

131. Singh, R.B. and Grover, A.: Urban-industrial development, environmental pollution and human health: A case study of East Delhi. In Akhtar, R. (Ed.) Climate change and human health in South and Southeast Asia: Prospects and challenge. Springer Nature Switzerland, Cham: pp. 113-130, 2016.

132. Singh, R.B. and Grover, A. (2015) Spatial correlations of changing land use, surface temperature (UHI) and NDVI in Delhi using Landsat satellite images. In Singh, R.B. (Ed.) Urban Development Challenges, Risks and Resilience in Asian Megacities. Springer Nature Japan, Tokyo: pp. 83-98, ISBN: 9784-431-55042-6 (Print) 978-4-431-55043-3 (Online).

133. Grover, A. and Singh, R.B. (2015) Urban pollution, health and sustainable development in Delhi. In Condie, J. and Cooper, A.M. (Eds.) Dialogues of sustainable urbanisation: Social Science research and transitions to urban context. Penrith: University of Western Sydney, pp. 215-217 (chapter 47).

134. Singh, R.B., Haque, S. and Grover, A. 2015. Drinking water, sanitation and health in Kolkata Metropolitan city: Contribution towards urban sustainability. Geography, Environment and Sustainability, 8 (4): 6481, ISSN: 2071-9388.

135. Sen Roy, Shouraseni and R.B. Singh. 2015: Role of local level relative humidity on the development of urban heat island across the Delhi Metropolitan Region. In: R.B. Singh (ed.), Urban Development Challenges, Risks and Resilience in Asian Mega Cities. Springer Nature Japan, Tokyo: pp. 99- 118, 2015.

136. Singh, R.B. and Kumar, Ajay: Vulnerability of Agriculture to Climate Change in arid Regions: A Case Study of Western
Rajasthan, India. In: Vulnerability of Land systems in Asia, Eds. Ademola K. Braimoh and He Qing Huang. Wiley Blackwell, Chester: pp. 77-90, 2015.

137. Singh, R.B. and Kumar, Dilip (2014). Water Scarcity. In: Handbook of Engineering Hydrology: Environmental Hydrology and Water Management. Taylor \& Francis Group, 519-544.

138. Suraj Mal and Singh, R.B.: Changing glacial lakes and associated outburst floods risks in Nanda Devi Biosphere reserve, Indian Himalaya. IAHS Publ. 364, pp. 255-260, 2014.

139. Singh, R.B. and Kumar, Dilip: Land-use planning for Sustainable Development Using Geoinformatics: Policy Implications for Drylands. In: Developments in Soil Classification, Land use planning and Policy Implications, Eds. S.A. Shahid et al., Springer Nature Science, Dordrecht, pp.563-575, 2013.

140. Singh, R.B., Gahlot S., and Kumar, Ajay: Environmental Implications of Depleting Traditional Water Bodies in NCT of Delhi. SLUAS Science Report. Asahikawa, pp. 5158, 2013.

141. Singh, R.B., B.P. Singh and Pram Jit: Drought Monitoring using Standarized Precipitation Index: Indian Experience. SLUAS Science Report. Asahikawa, pp. 5970, 2013.

142. Singh, R.B. and Kumar, Dilip: Spatial Information Technology for Land Use Based Integrated Watershed Management in Son-Karamnasa Interfluve. In: Towards Sustainable Land Use in Asia (III), Ed. Y. Himiyama. SLUAS Science Report, Asahikwa, pp. 67-87, 2012.

143. Singh, R.B. and Mal, Suraj: Land Use Environment and Development in the Uttarakhand Himalaya, India. In: Towards Sustainable Land Use in Asia, Ed. Yukio Himiyama. SLUAS Science Report 2010, Hokkaido University of Education, Asahikwa, pp. 47-64, 2010. 
144. Singh, R.B.: Land Use/Cover Change, Environment and Climate Change in Delhi Metropolitan Region: Towards Promoting Sustainable City. In: Proceedings of the Int. Symp. On Sustainable Urban Environment. Tokyo Metropolitan University, Tokyo, pp. 73-79. 2007.

145. Singh, R.B. and Bortamuly, M.: Impact of Floods on Biodiversity in the Brahmputra Valley. In: Proceedings of the International Conference on Monitoring, Prediction and Mitigation of Water-Related Disasters, Eds Takara, K et al., Kyoto University, Kyoto, Japan, pp. 599-606, 2005.

146. Singh, R.B. and Mishra, P.: Forest-Cover Mapping of Uttaranchal State, India. In: Understanding Land-Use and Land-Cover Change in Global and Regional Context, Eds Milanova, E. et al. Science Publisher, Inc Enfield (NH), USA. Pp 249-258, 2005.

147. Singh, R.B. and Singh, Anju: Water and Environment Related Disasters and Vulnerability in Indian Mega Cities: Case of Delhi Metropolitan Region. In: Proceedings of the International Conference on Monitoring, Prediction and Mitigation of Water-Related Disasters, Eds Takara, $\mathrm{K}$ et al.. Kyoto University, Kyoto, Japan, pp. 691606, 2005.

148. Singh, R.B. and Mishra, P.: Remote Sensing Based Land Use and Cover Change Monitoring as an Hydrological Indicator of Sustainability in the Himalayan Ungauged Basin. In: Sustainable Water Resources Management in the Changing Environment of the Monsoon Region, Vol. 1 Eds. S. Herath et al. UNU and Nat. Water Resources Secretariat, Sri Lanka, Colombo, pp.425-31, 2004.

149. Singh, R.B. and Kumar, Dilip: Monitoring, Mapping and Mitigation of Flood Disaster in India Using Remote sensing and GIS: A Case Study. In: Monitoring, Prediction and Mitigation of Disasters by Satellite Remote Sensing, Eds. K. Takara et al. DPRI, Kyoto University, pp. 53- 59, 2004.

150. Singh, R.B.: Local Knowledge and community participation in water management for poverty alleviation: towards integrating water science and ethics in India. In: Proceedings of the AsiaPacific Association of Hydrology and Water Resources, Eds. K. Takara and Kojiima, Disaster Prevention Inst., University of Kyoto, Japan, 2003.

151. Singh, R.B.: Tourism Development and Environmental Implications for the Indian Frontier Region: A Study of Himachal Himalaya. In: Tourism in Frontier Areas, Eds. Shaul Krakover and Yehuda Gradus. Lexington Books, Lanham, Maryland, pp.177-94, 2002.

152. Singh, R.B.: Environmental Degradation and its impact on Land Use/Land Cover Changes in Agriculturally Developed Regions of India. In: Proceedings of the IGU-LUCC International Conference, Eds. I. Blicik et al. Charles University, Prague, pp. 67-74, 2002.

153. Singh, R.B. and Kumari, Smriti: Environmental Implications of the Tala Hydro Electric project, Bhutan. In: Wasserwirtschaft im Wandel, Ed. A. Hoffmann, Kasseler WasserbauMitteilungen, Number 12. Herkules Verlag Kassel, pp. 165-174, 2001.

154. Singh, R.B.: Hazard-induced Hydrological problems in Himalayan Watershed - A study of an Indian Hot Spot. In: Hydrological Challenges in Transboundary Water Resources Management. UnescoIHP/OHP Secretariat, Koblenz, pp. 75-80, 2001.

155. Singh, R.B. and Parijat, Rakhi: Ecological Impact of Land Use Change in Delhi Ridge: Anthropogenic Stress and Spatial Realities. In: Urban Sustainability in the Context of Global Change, Ed. R.B. Singh, Science Pub., Inc., Enfield (NH), USA, pp.189-201, 2001.

156. Singh, R.B. and Kumar, B.: Sources of Air Pollution Emissions in Selected Metropolitan Cities of India. In: Urban Sustainability in the Context of Global Change, Ed. R.B. Singh, Science Pub., Inc., 
Enfield (NH), USA, pp.29-48, 2001.

157. Singh, R.B. and Mathur, A.: Large -scale Dams as Drivers of Land Use/cover Change in the Tropical Deciduous Forests - A Case Study of Sardar Sarovar Project (SSP), India. In: Land Use and Cover Change, Eds. R.B. Singh, J. Fox and Yukio Himiyama. Science Pub., Inc., Enfield (NH), USA, pp.139-153, 2001.

158. Singh, R.B. and Jag Mohan: Diversification of Rural Agricultural Land Due to Urban Intrusion-A Case -Study of the Metropolitan Periphery of Delhi, India. In: Land Use and Cover Change, Eds. R.B. Singh, J. Fox and Yukio Himiyama. Science Pub., Inc., Enfield (NH), USA, pp. 155-168, 2001.

159. Singh, R.B.: Urbanization in India's metropolis Delhi: Problem and Perspectives. In: Resolving Urban Environmental and Spatial Conflicts, Eds. Donald Miller \& Gert De Roo. Geo Press / Geo Pers Pubs. Groningen, pp. 27-37, 2000.

160. Druijven, P.C.J. and Singh, R.B.: The Depletion of Common Lands in the RuralUrban Fringe of Delhi: A Case Study of Unsustainable Development. In: Dimensions of Sustainable Rural Systems, Eds. I.R. Bowler, et. al. Groningen: Netherlands Geographical Studies, pp. 105-14., 1998.

161. Singh, R.B.: Impact of Agriculture and Land Use/Cover Change on Soil and Water Resources and Ecosystem Sustainability: A Case Study of Punjab. In: Sustaining Rural Systems in the context of Global Change, Ed. R. Epps. Armidale: Univ. of New England, 1998, pp. 335-42.

162. Singh, R.B. and Pandey, B.W.: Impact of Tourism on Ecohydrology in the Headwater Region of the Beas, Himachal Pradesh, Ecohydrology of High Mountain Areas, Eds. S.R.Chalise et al., Kathmandu: ICIMOD, 1998, pp. 519-525.

163. Singh, R.B.: Environmental Change study using Land use/Cover Data in LIS
Framework in India, Information Bases for Land Use/Cover Change Research. In: Proceedings IGU SG LUCC, Eds. Yukio Himiyama and L. Crissman, 1997. Asahikawa: Hokaido University of Education. pp. 98-104.

164. Singh, R.B.: Environmental, Economic and Social Sustainability through Human Development Initiatives: Case study of an Indian Marginal Region- Upper Kullu Valley. In: Proceedings of IGU SG Meeting Dev. Issues in Marginal Regions, Eds. G. Jones et al., 1997, Glasgow: University of Strathclyde.

165. Singh, R.B.: Challenges and Crisis of Sustainability and Opportunities for Resource Management in Indian Himalaya. In: Proceedings of NASDA/UNCRD/ICIMOD seminar on Space Informatics for Sustainable Development. Nagoya, UNCRD, Proceeding series No.21, 1997 pp. 51-60.

166. Singh, R.B.: Monitoring Tropical Geosystem, Underground Topography and Potential Water Resources for Sustainable Development using Geoinformatics - Indian Case Study. In: Proceedings of the 12th International Congress of Speleology, Ed. Pierre-Yves Jeannin, La Chaux-de-Fonds, pp. 369-372. 1997.

167. Berkes, F. et al.: Sustainability of a Mountain Watershed in the Himachal Pradesh Himalaya: Background and Overview, (jointly with several including R.B. Singh). In : Sustainability of Mountain Environment in India and Canada, Eds. F. Berkes and J.S. Gardner. University of Manitoba, Winnipeg, 1997, pp. 19-48.

168. Gardner, James, Pandey, B.W. and Singh, R.B.: Risk from Natural Hazards in the Manali Area. In: Sustainability of Mountain Environments in India and Canada, eds. F. Berkes and J.S. Gardner. Winnipeg, University of Manitoba, pp. 237-254, 1997.

169. Singh, R.B.: Environmental Monitoring and Natural Resource Management in Indian Arid Region using Space Informatics. In: Proceedings of the International Symp. on 
the Role of Remote Sensing for the Environmental Issues in Arid and Semi-Arid Regions, Eds. S. Shindo and A. Kondoh, CERES, Chiba University, Chiba-Tokyo, pp. 9-21, 1997.

170. Pandey, B.W. and Singh, R.B. and.: Snow Melting Variation and Regional Environmental Change - A Micro-Level Study of Himalayan Rivers. In: Proceedings of CGB Symp. on Global Change and the Commonwealth, ed. Yue-man Yeung. Hong Kong: the Chinese University of Hong Kong, pp. 433-45, 1996.

171.Singh, R.B.: Remote Sensing and GIS Based Land Use Information System for Natural Resource Monitoring and Management: The Indian Experience. In: Proceedings of Int. Workshop held at Ullan Bataar. Nagoya, UNCRD, pp. 99-106, 1996.

172. Singh, R.B. and Pandey, B.W.: Landslide Hazard in Indian Himalaya and Canadian Rockies: A Comparative Analysis. In: Proceedings of the Eighth Int. Conf. on Landslides, Eds. J. Chacon, et al. Rotterdam: A.A. Balkema, pp. 63-69,1996.

173.Singh, R.B.: Recent Earthquake in Maharashtra, India: Uncertainty, Existing Reality, and Task Ahead in Disaster Management in Metropolitan Areas for the 21st Century In: Proceedings of the IDNDR Aichi/Nagoya Int. conf. UNCRD, Nagoya also in, Research in Geography, Disasters and Environment: Monitoring and Forecasting, eds. R.B. Singh, New Delhi, APH Pub., Vol. II, pp. 83-89, 1996.

174. Singh, R.B.: Land Use, Development and Environmental Criticality in Marginal Regions: A Case Study of Himachal Pradesh. In: Marginality and Development Issues in Marginal Regions, Ed. Chang-Yi David Chang. Taipei, National Taiwan University, 1994. pp. 19-40; also published in: Contemporary Approaches to Indian Geography, Ed. Rais Akhtar, pp. 109-140, 1997.

175. Singh, R.B.: Desert Region in India: Resource Management Issues and
Research Strategy. In: Towards Solving the Global Desertification Problems, eds. T. Miyazaki and A. Tsunekawa, Tsukuba: NIES pp. 1-18, 1994. Also, pub. in, Environmental Strategies, Ed. R. M. Lodha, New Delhi, 1993.

176. Singh, R.B.: Monitoring Soil Loss and Sediment Deposition in Indian Perspective. In: Erosion and Sediment Transport Monitoring Programmes in River Basins, Ed. Jim Bogen, NWREA, Oslo, 1992. pp. 138-42.

177. Singh, R.B.: Remote Sensing Data Base and GIS Projects for Monitoring National Environmental Change in India. In: Environmental Change and GIS, Eds. I. Ota, Proc. of INSEG -1991, Vol. 2. Pp. 344-51.

178. Singh, R.B.: Role of Geographical Monitoring and Forecasting in Ecosystem Modelling and Management: The Indian Experience. In: Proceedings of the UNESCO/MAB Seminar on Future Research Trends, Ed. - Y. Aruga. MAB, Tokyo: MAB, 1991, pp. 209-252; also in: Global Environmental Change-Perspectives on Remote Sensing and GIS, Ed. R.B. Singh. New Delhi, Oxford \& IBH Pub., pp. 1-21, 1995.

179. Singh, R.B. and Khan, A.R.: Domestic Energy Use in Delhi Metropolitan Fringe: A Study of Rural and Urban Villages. In: Proc. of 10th Int. Symp. on Asian Studies. Hong Kong; ARS, 1989, pp. 1003-2009.

180. Singh, R.B.: The state of environmental and Resource Management in Drylands of North India. In: Resource Management in Drylands, Eds. W. Mecalien, et al. Stuttgarter (Germany): Stuttgarter Geographische Studien, 1985, pp. 127-40; also published in: Indian Desert : Resources and Perspectives Development, ed. T.S. Chauhan, Jaipur, Printwell: pp. 254-62, 1995.

181. Singh, R.B. and Singh, M.P.: Spatial Organisation of Service Centres: case of Jaunpur District. In: Proceedings of IGU Symp. on Rural Development. Liege ( 
Belgium), Ed. Ch. Christians, 1983, pp. 32135.

182. Singh, R.B.: Ecological Approach of Irrigation System: Potentiality Constrains and Management in Traditional Society. In: Problems of the Management of irrigated Land in Areas of Traditional and Modern Cultivation, Ed. H.G. Mensching. Proceedings of the IGU Working Group Symp., Cairo-El-Minia (Egypt), Hamburg (Germany), 1983, pp. 123-32.

183. Singh, R.B.: Transformation of Agriculture for Rural Development: The Indian Micro Level Experience. In: Changing Scene of Rural Habitat in Developing Countries, Eds. Shogo Yuihama and Rana P.B. Singh. The $24^{\text {th }}$ IGU Tokyo pub., Okayama National University: Geography Department, 1980, pp.145-53.

184. Singh, R.B.: Rural Spatial Taxonomy for Integrate Rural Development: The Indian Experience. In: Changing Scene of Rural Habitat in Developing Countries, Eds. Shogo Yuihama and Rana P.B. Singh. The $24^{\text {th }}$ IGC Tokyo Pub., Okayama National University: Geography Department, 1980, pp. 129-44.

\section{Papers in the Indian Books and Proceedings} (76: Se 185 to 260, cf. Table 9)

185. Singh, R.B. and Singh, Rana P.B.: Incredible India: Geographical Mosaic of Natural and Cultural Heritage Landscapes. In: (IGU-India Editors) Progress in Indian Geography. A Country Report, 2016-2022. The 100th Anniversary Centennial International Geographical Congress, Paris, France, Turkey (July 18-22, 2022). Indian National Science Academy, New Delhi: ca pp. 25-54. > An open access electronic publication, 2022.

186. Singh, R.B. and Kumar, Rajesh: Climate Change Research: Status and Methodology. In: Management of Natural Resources for Sustainable Development, Eds. B.S. Rathor and V.S. Rathor, Daya Pub. House, New Delhi, pp.219-45, 2013.

187. Misra, R.P.,Thakur, B. and Singh, R.B.:
Thimphu: The City of Peace and Organic Development. In: Urbanisation in South Asia - Focus on Mega Cities, Ed. R.P. Misra, Cambridge University Press, New Delhi, pp. 398-420, 2013.

188. Goswami, Nitu, Singh, R.B. and Kala, C.P.: Herbal Home Remedies and Role of Traditional Healers as Health Care Providers. In: Sustainable Use of Medicinal Plants, Ed. R.N. Pati, Abhijeet Pub., New Delhi, pp. 197-210, 2012.

189. Singh, R.B. and Gurjar, A.K.: Economic Reforms and Employment Generation and Inclusive Growth in India. In: New Economic Policies and Employment Opportunities in India, Eds. B.S. Yadav, et al. Shree Pub., New Delhi, pp.1-12, 2012.

190. Singh, R.B.: Designing and Shaping Global to Local Environmental Education: The Indian Experience, Pub. In: Global Environnemental Education, Eds. Yukio Himiyama, et al. Rawat Publications, Jaipur, pp. 62-80, 2010.

191. Singh, R.B.: Forest Resources, Biogeography and Biodiversity: Indian Experience. In: Biogeography and Biodiversity, Ed. R.B. Singh. Rawat Publications, Jaipur, pp.1-21, 2009.

192. Singh, Mehtab, Kumar, Suresh, Singh, R.B. and Kala, P.M.: Remote Sensing and GIS Based Modelling Approach for Land Capability Classification (Case Study of East Dehradun Valley). In: Land Use, Biodiversity and Climate Change, Eds. R.B. Singh, et al. MMC College, Marthandam, pp.13-26, 2009.

193. Singh, R.B. and Mal, Suraj: Landslides Hazard and its Influences on Biodiversity in Nanda Devi Biosphere Reserve. In: Biogeography and Biodiversity, Ed. R.B. Singh. Rawat Publications, Jaipur \& New Delhi, pp.1-21, 2009.

194. Singh, R.B. and Singh, Mehtab: Geographical Analysis of Water logging Induced Land Degradation in Karnal District of Haryana. In: Perspectives in Resource 
Management in Developing Countries, vol. 3, Ed. Baleshwar Thakur, Concept Pub. Co., New Delhi, pp. 196-211, 2008.

195. Singh, R.B.: Local Governance in Disaster Management through Vulnerability Analysis and Mitigation. In: Disaster Management in India-Perspective, Issues and Strategies, Eds. N. Rai and A.K. Singh. New Royal Book, Lucknow, pp. 93-107, 2007.

196. Singh, R.B. and Singh, Swarnima: Temporal Transport Hazard Dynamics: A Case Study of Delhi. In: Disaster Management: Future Challenges and Opportunities, Ed. Jagbir Singh. Int. Pub. House, New Delhi: pp. 95112, 2007.

197. Singh, R.B. and Singh, Swarnima: Challenges of Flood Disaster Management: A Case Study of NOIDA. In: Disaster Management: Future Challenges and Opportunities, Ed. Jagbir Singh, I.K. Int. Pub. House, New Delhi: pp. 15-30, 2007.

198. Singh, R.B. and Prakash, Nawal: Integrated Watershed Management for Livelihood Security:A Case Study of Uppalgaon Watershed, Uttaranchal Himalaya. In: Use and Misuse of Land and Water Resources, Ed. Abha Lakshmi Singh. B.R. Pub., Delhi, pp. 113-127, 2006

199. Singh, R.B.: Introduction to Natural Hazards and Disasters: Conceptual Framework, Vulnerability, Spatial Pattern, Impacts and Mitigation Strategy: Indian Experience. In: Natural Hazards and Disaster Management, Ed. R.B. Singh. Rawat Pub., Jaipur, pp. 3-39, 2006.

200. Singh, R.B.: Tsunami Disaster in India: Warning, Responses, Impacts and Mitigation. In: Natural Hazards and Disaster Management, Ed. R.B. Singh. Rawat Pub., Jaipur, pp. 104-119, 2006.

201. Gardner, J.S. and Singh, R.B.: Urban Development and Environmental Impacts in a Mountain Context. In: Sustainable Urban Development, Ed. R.B. Singh. Concept Pub. Co., New Delhi, pp. 67-86,
2006.

202. Singh, R.B. and Mishra, D.K.: Slums, Environment and Development in Metropolitan Cities of India. In: Sustainable Urban Development, Ed. R.B. Singh. Concept Pub. Co., New Delhi, pp. 261-271, 2006.

203. Singh, R.B. and Jag Mohan: Brick Kiln Industry as Drivers of Land Use Change and Related Land Degradation in Rural-Urban Fringe of Delhi. In: Sustainable Urban Development, Ed. R.B. Singh. Concept Pub. Co., New Delhi, pp. 279-288, 2006.

204. Singh, R.B. and Shouraseni Sen Roy: Influence of water availability on poverty in India. In: S.C. Kalwar, M.L. Sharma, R.D. Gurjar, M.K. Khandelwal and S.K. Wadhawan (eds), Geomorphology and Environmental Sustainability (Felicitation volume in honour of Professor H. S. Sharma). Concept Pub. Co., New Delhi, pp. 319-327, 2005.

205. Singh, R.B. and Kumar, Dilip: Geoinformatics for Sustainable Development-A case Study of Ferozpur Jhirka Block of Gurgaon District in Haryana. In: Geoinformatics Applications for Sustainable Development, Eds. A.K. Singh, et al. ISRS (Delhi Chapter) and IARI, New Delhi, pp.126-33, 2004.

206. Singh, R.B. and Mishra, D.K.: Agricultural Transformation and Rural Sustainability in a Himalayan Watershed: Case Study of Kullu Valle. In: Resource Conservation and Food Security, Ed. T. Singh, Concept. Pub. Co., New Delhi, pp. 345-55, 2004.

207. Singh, R.B. and Sen Roy, Shouraseni: Impact of Climate Change on Mountain Ecosystems. In: Assessment of Climate Change in India, Eds. S.K. Das and Prakash Rao. World Wide Fund for Nature (WWF), New Delhi, 221-230, 2004.

208. Singh, R.B.: Remote Sensing and GIS for Resource Management in India. In: Perspectives in Resource Management in Developing Countries, Vol. 1-Resource 
Management: Theory and Techniques, Ed. Baleshwar Thakur. Concept Pub. Co., New Delhi, pp. 485-99, 2003.

209. Singh, R.B. and Kumar, Bhuwan: Urban Environmental Data Base, Planning and Policies. In: Management of Environmental Pollution, Eds. Anju Kohli, et al. Book Enclave, Jaipur, pp. 252-69, 2003.

210. Singh, R.B.: Himalayan Environment, Land Use Cover Changes and Highland Lowland Interactive System with Indus-Ganga Brahmaputra Plains. In: Land Use Historical Perspectives - Focus on IndoGangetic Plains, Eds. Y.P. Abrol, et al. Allied Pub., New Delhi, pp. 475-98, 2002.

211. Singh, R.B.: Environmental Impact and Response Analysis of Urban and Tourism Infrastructure Development in the Himachal Himalaya. In: Recent Advances in Geomorphology, Quaternary Geology and Environmental Geosciences: Indian Case Studies, Eds. S.K. Tandon and B. Thakur. Manisha Pub., New Delhi, pp. 385-94., 2002.

212. Singh, R.B.: Land Use Planning in Resettlement and Rehabilitation Areas in Highlands. In: Human Dimensions of Sustainable Development, Ed. R.B. Singh. Rawat Pub., Jaipur, pp. 254-266, 2002.

213. Singh, R.B. and Pandey, B.W.: Landslide Hazard in Himachal Himalaya. In: Geoenvironmental Hazards, Eds. V. Subramanian and Jayakumar. UNESCOENVIS, New Delhi, pp. 71-84, 2000.

214. Singh, R.B. and Ghai, Sarita: Human Induced Hazards and Development in a part of Upper Yamuna Watershed, Garhwal Himalaya, In: Contributions to Environmental Geoscience, Eds. A.M. Pathan and S.S. Thigale. Aravali Books Int., New Delhi, pp. 151-160. 2000.

215. Singh, R.B.: Environmental Impact Assessment and Management in Highlands and Headwater Regions. In: Environmental Impacts Assessment of Water Resources Projects, Ed. R.S. Goel, Oxford \& IBH. Pub.,
New Delhi, pp. 343-356, 2000.

216. Singh, R.B. and Mishra, D.K.: River Pollution as Environmental Disaster in Yamuna at Delhi: Perspectives for $21^{\text {st }}$ Century. In: Disaster Management, Ed. R.B. Singh. Rawat Pub., Jaipur, pp. 319-330, 2000

217. Srivastava, A.K. and Singh, R.B.: Governmental Response to Flood Disaster Preparedness, Relief and Mitigation in Haryana. In: Disaster Management, Ed. R.B. Singh. Rawat Pub., Jaipur, pp. 308-318, 2000

218. Singh, R.B. and Tingal, D.: Man-made and Natural Geo-Hazards in Kullu Valley. In: Disaster Management, Ed. R.B. Singh, Rawat Pub., Jaipur, pp. 259-286, 2000

219. Singh, R.B.: Remote Sensing and GIS for Disaster Management. In: Disaster Management, Ed. R.B. Singh. Rawat Pub., Jaipur, pp. 11-24, 2000.

220. Singh, R.B. and Babar Ali, M.: Dynamics of Village Common Land and its Sustainable Management in the Himalayan Upper Beas Basin. In: The Himalayan Environment, Eds. S.K. Dash and J. Bahadur, New Age International (P) LTD-Pub., New Delhi, pp. 246-257, 1999.

221. Singh, R.B.: Geographic Information System for Environmental Monitoring and Management. In: Proceedings of National Seminar on Environmental Management in Hydro Electric Projects, New Delhi, 1999, Ministry of Environment \& Forests, Govt. of India, Organised by Institute for Resource Management and Economic Development, pp. 119-128., 1999; also published in Geographic Information System as a Tool of Environmental Decision Making, Ed. B. Misra. Proceedings of SCADA Conference, New Delhi: Mittal Pub., 1998.

222. Mishra, B., Singh, R.B. and Malik, Anupama: Delhi Metropolis: Housing and Quality of Life. In: Million Cities of India, vol. 1, Eds. R.P. Misra and K. Misra, New Delhi: Sustainable Development Foundation, pp. 196-228, 1998. 
223. Grewal, Varinder S., and Singh, R.B.: Status of Environmental Quality and Decisionmaking in India: Past, Present and Future Trends. In: Techniques and Approaches to Vulnerable Environment, Ed. R.B. Singh. New Delhi: Oxford and IBH Pub., pp. 35068, 1998.

224. Verma, Romila P. and Singh, R.B.: Dam and Water Resource Development: Myth or Reality - Case of Hirakud Dam. In: Ecological Techniques and Approaches to Vulnerable Environment, Ed. R.B. Singh. New Delhi: Oxford and IBH Pub., pp. 223242, 1998.

225. Singh, R.B. and Murai, S.: Earth Science Data and Information Technology Network Development in India. In: Space Informatics for Sustainable Development, Eds. R.B. Singh and S. Murai. New Delhi: Oxford \& IBH Pub., pp. 47-62. 1998.

226. Singh, R.B.: Understanding High Mountain Land Use Towards Sustainable Environmental in Jammu and Kashmir. In: Headwaters - Water Resources and Soil Conservation, Eds. Martin J. Haigh, et al. New Delhi: Oxford \& IBH Pub. 1998, pp. 409-422.

227. Haigh, Martin J., Krecek, J. and Singh, R.B.: Headwater Control: Matters Arising. In: Headwaters- Water Resources and Soil Conservation, Eds. Martin J. Haigh, et al. New Delhi: Oxford \& IBH Pub., 1998, pp. 324.

228. Singh, R.B. and Ghai, Sarita: Genesis and Impacts of a Landslide - The Case Study of Kharadi-Khanera Slope Section, U.P. Himalaya. In: Sustainable Development of Mountain Environment in India and Canada, Ed. R.B. Singh, New Delhi: Oxford \& IBH Pub., 1998, pp. 298-308.

229. Singh, R.B. and Pandey, B.W.: Forest and Forestry: Degradation and Renewal in Arrow Lake Forest District, British Columbia, Canada. In: Sustainable Development of Mountain Environment in India and Canada, Ed. R.B. Singh. New Delhi: Oxford \& IBH Pub., 1998, pp. 242-
256.

230. Pandey, B.W. and Singh, R.B.: Environmental Hazards and Mitigation Measures in Upper Arrow Lake Region, British Columbia, Canada. In: Sustainable Development of Mountain Environment in India and Canada, Ed. R.B. Singh, New Delhi: Oxford \& IBH Pub., 1998, pp. 217241.

231. Singh, R.B., Pandey, B.W. and Singh, Tripta: Population, Urbanization and Tourism in Kullu District. In: Sustainable Development of Mountain Environment in India and Canada, Ed. R.B. Singh, New Delhi: Oxford \& IBH Pub., 1998, pp. 153-171.

232. Singh, R.B.and Babar Ali, M.: Village Common Land in Upper Beas Basin. In: Sustainable Development of Mountain Environment in India and Canada, Ed. R.B. Singh, New Delhi: Oxford \& IBH Pub., 1998, pp.126-141.

233. Singh, R.B. and Gurudatt, G.N.S.:

Environmental Stress of Forest Degradation on Erosional Intensity: A Micro-level Study of Solan District. In: Sustainable Development of Mountain Environment in India and Canada, Ed. R.B. Singh, New Delhi: Oxford \& IBH Pub., 1998, pp. 113125.

234. Singh, R.B., Bas, Kirti and Datta, P.: Environmental Stress of Horticulture on Sustainable Livelihood and Food Security in Kullu Valley. In: Sustainable Development of Mountain Environment in India and Canada, Ed. R.B. Singh, New Delhi: Oxford \& IBH Pub., 1998, pp. 98-112.

235. Singh, R.B. and Mishra, D.K: Environmental Implications of Land use Change and Forest Degradation in Upper Beas Basin. In: Sustainable Development of Mountain Environment in India and Canada, Ed. R.B. Singh, New Delhi: Oxford \& IBH Pub., 1998, pp. 76-85.

236. Singh, R.B. and Ghai, Sarita: Environmental Disasters in Marginal Areas: A Study of Road Construction Induced Impacts in a 
Himalayan Yamuna Catchment. In: Development Issues in Marginal Regions, Eds R.B. Singh and R. Majoral. Oxford \& IBH Pub., New Delhi, pp. 311-20, 1996.

237. Druijven, P.C.J. and Singh, R.B.:

Environmental Degradation and its Impact on Livelihood Strategies in the Urban Fringe of Delhi-Some Theoretical Reflections. In: Disasters, Environment, and Development, Ed. R.B. Singh, Oxford \& IBH pub, New Delhi, pp. 355-68, 1996.

238. Singh, R.B.: Disasters Monitoring and Mitigation. In: Disasters, Environment, and Development, Ed. R.B. Singh, Oxford \& IBH pub, New Delhi, pp. 31-62, 1996.

239. Singh, R.B. and Pandey, B.W: Hazard Zone Mapping and Risk Assessment Analysis in the Upper Beas Basin: CIDA-SICI Experience. In: Disasters, Environment, and Development, Ed. R.B. Singh, Oxford \& IBH pub, New Delhi, pp. 121-35, 1996.

240. Singh, R.B. and Pandey, B.W.: Perspectives for Managing Rural Water Resources: A Study of Ganga-Gomati Doab. In: Research in Geography: Land Use Changes and Sustainable Development, Eds. R.B. Singh. New Delhi, APH Pub., Vol. I, pp. 307-318, 1996.

241.Singh, R.B.: Sustainable Development Initiatives in Indian Geosystems: Case of Social Forestry. In: Research in Geography: Land Use Changes and Sustainable Development, Eds. R.B. Singh. New Delhi, APH Pub., Vol. I, pp. 127-38, 1996.

242. Rowbotham, D. and Singh, R.B.: The Importance of Natural Hazards Research to the Himalaya Region: Himachal Pradesh, a Case in Point. In: Global Environmental Change Perspectives of Remote Sensing and Geographic Information System, Ed. R.B. Singh. Oxford \& IBH Pub., New Delhi, 1995 pp. 185-199.

243. Singh, R.B.: The State of Environment and Resource Management in Drylands of North India. In: Resource Management in Drylands, Indian Desert: Resources and
Perspective Development, Ed. T.S. Chauhan. Jaipur, Printwell, pp. 254-262, 1995.

244. Singh, R.B. and Tingal, D.: Identification of Critical Environmental Zones in Kullu District. In: Sustainable Reconstruction of Highland and Headwater Regions, Eds. R.B. Singh and Martin J. Haigh. New Delhi, Oxford \& IBH Pub., pp. 627-638, 1995.

245. Singh, R.B. and Chauhan, G.S.: Land use Change and Land Information System in Kullu Valley.In: Sustainable Reconstruction of Highland and Headwater Regions, Eds. R.B. Singh and Martin J. Haigh. New Delhi, Oxford \& IBH Pub., pp. 639-647, 1995.

246. Singh, R.B. and Pandey, B.W.: Common Resources and Sustainable Livelihood of Mountain Environment: A Micro-Level Experience of Upper Kullu Valley. In: Sustainable Reconstruction of Highland and Headwater Regions, Eds. R.B. Singh and Martin J. Haigh. New Delhi, Oxford \& IBH Pub., pp. 663-681, 1995.

247. Singh, R.B.: Land Use Change, Diversification of Agriculture and Agroforestry in North-West India. In: Proceedings of Indo-British Seminar, Ed. A. Mukerji, 1994, New Delhi: Concept Pub. Co; also in: Global Environmental ChangePerspectives on Remote Sensing and GIS, Ed. R.B. Singh. New Delhi, Oxford \& IBH Pub., 1995, pp. 313-21. Also published in: Land Use Planning in India, Ed. T. Haque. New Delhi, NCAEPR, 1999, pp. 122-130.

248. Singh, R.B. and Chauhan, G.S.: Land Use Pattern, Land Degradation Hazard and Sustainability in the Indian Desert Region. In: Agroforestry Systems for Degraded Lands, Eds. P. Singh, et al. New Delhi: Oxford \& IBH Pub., pp. 13-19, 1994.

249. Singh, R.B. and Pandey, B.W.: Sikkim Himalaya: Geo Ecological System, SocioEconomic Change and People's Perception. In: Sikkim: Society, Polity, Economy and Environment, Ed. M.P. Lama. New Delhi, pp. 241-254, 1994. 
250. Singh, R.B. and Pirazizy, A.A.: Anthropogenic Impact on Landscape Synthesis in Kashmir Himalayas: A Study of Land Suitability and Capability

Classification. In: Frontiers in Environmental Geography, Eds. Onkar Singh, et.al., Concept Pub. Co., New Delhi, pp. 93-104, 1993.

251. Singh, R.B.: Micro-level Monitoring of Land Use and Agriculture in Himalayas. In: Land use and Agricultural Planning, Ed. Noor Mohammed, Concept Pub. Co., New Delhi, 1992, 227-41.

252. Pirazizy, A.A. and Singh, R.B.: Forest Energetic and Environmental Anomaly in Temperate Himalaya. In: Dynamics of Mountain Geosystems, Ed. R.B. Singh. New Delhi, Ashish Pub., 1992, pp. 87-100.

253. Singh, R.B.: Environmental Geography in India: Challenges and Opportunities. In: The Roots of Indian Geography: Search and Research, Eds. R.L. Singh and Rana P.B. Singh. Varanasi: National Geographical Society of India, NGSI Res. Pub. 39, 1992; also published as: 'Emerging Frontiers in Environmental Geography: An Introductory Overview', in: Environmental Geography, Ed. R B. Singh. New Delhi, Heritage Pub., pp. 1-23, 1990.

254. Singh, R.B.: Human Resource Base for Rural Development in a Mountainous Region. In: Human Resource Development, Vol. 1, Ed.
A. Kumar. Anmol Pub., New Delhi, 1991, pp. 207-22.

255. Singh, R.B.: Drought-Prone Areas in India: Regional Planning Issues and Resources Management Strategy. In: Planning, Development and Disparities in Rural India, Ed. Ashok Kumar. New Delhi: Commonwealth Pub., 1990.

256. Singh, R.B.: Integrated Rural Development: Concepts and Experience. In: Regional Development: Contributions to Indian Geography, vol. X, Ed. Moonis Raza. New Delhi: Heritage Pub. 1988, pp. 544-568.

257. Singh, R.B.: Spatial Perspective of
Population and Resource Management in Arid Environment: A Case Study of Western Rajasthan, India. In: Resource Management in Dry Lands, Eds. H.G. Mensching, et al. New Delhi, Oxford \& IBH Pub., 1984, pp. 206-214.

258. Kayastha, S.L. and Singh, R.B.: Settlement Planning and Integrated Rural Development in Micro-level Unit: A Case Study of Daraundha Block. In: Proceedings of the National Seminar on Regional Planning and Rural Development, Ed. L.R. Singh. Allahabad, 1984, pp.147-50.

259. Kayastha, S.L. and Singh, R.B.: Energy Resources and Technology Transfer in the Management of Rural Environment. In: Environmental Management, Eds. L.R. Singh, et al., Allahabad, 1983, pp. 80-89.

260. Singh, Rana P.B., Kayastha, S.L. and Singh, R.B.: Pattern and Prospects of Service Centres in Spatial Context, Case of the Siwan District. In: Rural Habitat Transformation in World Frontiers, Eds. R.L. Singh and Rana P.B. Singh. Varanasi: National Geographical Society of India, NGSI Res. Pub. No. 30, 1980, pp.108-116.

\section{APPENDIX: 2}

Prof. R.B. Singh: Ph.D. Thesis Supervised (39), 1992-2020 (cf. Table 10).

1. Anthropogenic Impact on Environmental Changes in Temperate Zone of the Himachal Himalayas; by Ali Akbar Pirazizy (1992).

2. Integrated Block Level Planning in Agriculturally Developed Region, (A Study of Kapurthala Block); by Lakhvinder Singh (1993).

3. Monitoring and Forecasting Hydrological Parameters in the Mahanadi River Basin; by Romila Prasad (1996).

4. Man-Forest Interactions in the Himalayan Yamuna Basin - A Geoecological Perspective; by Sarita Ghai (1998).

5. Atmospheric Quality in Metropolitan Cities of India; by Bhuwan Kumar (1998). [* In revised version published, co-authored with 
R.B. Singh; Manak Pub., New Delhi, 216-pp., 2003].

6. Environmental Implications of Farmland Diversification in Rural-Urban Fringe of Delhi; by Tejbir Singh Rana (2000)

7. Hazard Risk Assessment and Sustainable Land Development in Upper Beas Basin; by B.W. Pandey (2000).

8. Squatter Settlements of Delhi Metropolis - A Human Ecological Study; by Ravi Shekhar (2002).

9. Environmental Degradation and Development in the Metropolitan Fringe of Delhi; by Naval Prasad Singh (2003).

10. Changing Land use and Land Degradation Problems in the Indian Desert Region; by Gambhir Singh Chauhan (2003).

11. Impact of Land Use Change on Biophysical and Socio-Economic Systems of Upper Beas Basin; by D.K Mishra (2003).

12. Geographic Dimensions of Common Land Resources in the Santhal Parganas Region; by Mohammed Baber Ali (2004).

13. Population, Land Use and Environmental Sustainability in Haryana; by Suman Chauhan, joint Supervisor submitted at M.D. University, Rohtak (2005).

14. The Changing Pattern of Domestic Energy Consumption and its Impact on Quality of Life: A case Study of National Capital Region (NCR); by V.K. Dixit (co-supervision) (2006).

15. Traffic and Environmental Assessment A Case Study of Delhi; by Ms. Rakhi Mukherjee (2007).

16. Cyclone Disaster Vulnerability and Mitigation along the East Coast of India; by Ms. Ushvinder Kaur (2008).

17. Management of Municipal Solid Waste in Urban Delhi: A Geographical Analysis; by Subhash Anand (2008).

18. Impact of Land Use Change and Industrial Development on Atmospheric Quality in Agra Metropolitan City; by Vishwa Raj
Sharma (2008).

19. Influence of Environmental Degradation on Women in Rural Delhi; by Monica Rana (2008)

20. Land and water Resource Management in Son-Karamnasa Interfluve in Bihar; by Dilip Kumar (2009).

21. Spatial Analysis of Water Quality in River Yamuna and its Interrelationship with Human Activities in NCT of Delhi; by Vaneeta Chandana (2009).

22. Environmental Implications of Agricultural Development in Patiala District, Punjab; by Neha Arora (2011).

23. Forest Resource Assessment: A Case Study of Dehradun Valley; by Ms. Poonam Kumaria (2011).

24. Hazards and Associated Risks in Upper Bhagirathi Basin; by Subodh Kumar (2011).

25. Monitoring Land Use Change and its Environmental Impacts in Jaipur City using Geoinformatics; by R.K. Gupta (2011)

26. Assessment of Integrated Watershed Development Programme in Haryana Shiwalik; by Mehtab Singh (2012).

27. Influence of Climate Change on Nanda Devi Biosphere Reserve; by Suraj Mal (2013).

28. Glacier Lake Outburst Flood and Associated Geohazards in Himachal Himalaya; by Pankaj Kumar (2013).

29. Agriculture Vulnerability to Climate Change in Rajasthan 1950-2010; by Ajay Kumar Gurjar (2015).

30. Resource Base and Livelihood Strategies in Selected Panchayats of Himachal Pradesh; by Anjali Yadav (2015).

31. Climate Change and Livelihood Security in Kangra District; by Swarnima Singh (2015). [ ${ }^{*}$ In revised version published, co-authored with R.B. Singh; Springer Nature Pte Ltd., Singapore, 2021].

32. Urban Health and Wellbeing in Changing Urban Environment: A Comparative Study of 
Delhi and Mumbai; by Aakriti Grover (2017). [* In revised version published, co-authored with R.B. Singh; Springer Nature Pte Ltd., Singapore, 2020.].

33. Livelihood Security in Changing SocioEconomic Environment in Kangra District of Himachal Pradesh; by Nitu (2018).

34. Relationship Between Monsoon Rainfall, Aerosols and its Environmental Implications in the National Capital Region; by Mansi Janmaijaya (2019).

35. Drought Vulnerability, Impact and risk reduction: A case study of Marathwada Region; by Sagar Khetwani (2019).

36. Landslide risk Assessment Along the Major Transport corridor: A case study of Kullu-
Rohtang Pass; by Nirbhav (2019).

37. Modelling Urban Growth Dynamics and Sustainability in Dehradun City; by Aruna Paarcha (2020).

38. Impact of Climate Change on Nutrition and Health in Mountain Region: A case study of Kumaun Himalaya; by Arti (2020).

39. Environment, Exposure and Diseases: An Epidemiological Assessment of Urban Health in Kolkata; by Senaul Haque (2020).

Note: * Doctoral dissertation published in revised version, co-authored with R.B. Singh (himself supervisor). 